This document is confidential and is proprietary to the American Chemical Society and its authors. Do not copy or disclose without written permission. If you have received this item in error, notify the sender and delete all copies.

\title{
Novel water-soluble mucoadhesive carbosilane dendrimers for ocular administration
}

\begin{tabular}{|c|c|}
\hline Journal: & Molecular Pharmaceutics \\
\hline Manuscript ID & Draft \\
\hline Manuscript Type: & Article \\
\hline Date Submitted by the Author: & $\mathrm{n} / \mathrm{a}$ \\
\hline Complete List of Authors: & $\begin{array}{l}\text { Bravo-Osuna, Irene; Universidad Complutense de Madrid Facultad de } \\
\text { Farmacia, Pharmaceutical Technology } \\
\text { Vicario-de-la-Torre, Marta; Universidad Complutense de Madrid Facultad de } \\
\text { Farmacia, Pharmaceutical Technology } \\
\text { Andrés-Guerrero, Vanessa; Universidad Complutense de Madrid Facultad } \\
\text { de Farmacia, Pharmaceutical Technology } \\
\text { Sánchez-Nieves, Javier; Universidad de Alcala, Organic and Inorganic } \\
\text { Chemistry } \\
\text { Guzmán Navarro, Manuel; Universidad de Alcala de Henares Facultad de } \\
\text { Medicina y Ciencias de la Salud } \\
\text { de la Mata, F. Javier; University of Alcalá, } \\
\text { Gómez, Rafael; University of Alcalá, Inorganic Chemistry } \\
\text { De las Heras, Beatriz; Universidad Complutense de Madrid. Facultad de } \\
\text { Farmacia, Pharmacology } \\
\text { Argüeso, Pablo; Harvard Medical School, Eye and Ear Department } \\
\text { Ponchel, Gilles; Université Paris-Sud 11, UMR CNRS } 8612 \\
\text { Herrero-Vanrell, Rocío; Universidad Complutense de Madrid Facultad de } \\
\text { Farmacia } \\
\text { Molina-Martínez, Irene; Universidad Complutense de Madrid Facultad de } \\
\text { Farmacia, Pharmaceutical Technology }\end{array}$ \\
\hline
\end{tabular}




\section{Novel water-soluble mucoadhesive carbosilane}

\section{dendrimers for ocular administration}

I. Bravo-Osuna ${ }^{a, b, c^{*}}$, M. Vicario-de-la-Torre ${ }^{a, b, c}$, V. Andrés-Guerrero ${ }^{a, b, c}$, J. Sánchez-Nieves ${ }^{d, e}$, M. Guzmán-Navarro ${ }^{f}$, F. J. de la Mata ${ }^{d, e}$, R. Gómez ${ }^{d, e}$, B. de las Heras ${ }^{g}$, P. Argüeso ${ }^{h}$, G. Ponchel ${ }^{i}, R$. Herrero-Vanrell ${ }^{a, b, c}$, and I. T. Molina-Martinez ${ }^{a, b, c}$

${ }^{a}$ Dept. of Pharmacy and Pharmaceutical Technology, School of Pharmacy, University Complutense. Avd. Complutense 28040 Madrid, Spain.

${ }^{b}$ Pharmaceutical Innovation in Ophthalmology Research Group, Sanitary Research Institute of the San Carlos Clinical Hospital (IdISSC) and the Ocular Pathology National Net (OFTARED) of the Institute of Health Carlos III. Calle Profesor Martín Lagos, s/n; 28040 Madrid, Spain.

c Instituto Universitario de Farmacia Industrial (IUFI). School of Pharmacy, University Complutense. Avd. Complutense 28040 Madrid, Spain.

${ }^{d}$ Dept. of Organic and Inorganic Chemistry, University of Alcalá. Pza. San Diego 28801, Alcalá de Henares, Spain.

${ }^{\mathrm{e}}$ Networking Research Center on Bioengineering, Biomaterials and Nanomedicine (CIBER-BBN). Pza. San Diego 28801, Alcalá de Henares, Spain.

${ }^{\mathrm{f}}$ Dept. of Pharmacy and Pharmaceutical Technology, School of Pharmacy, University of Alcalá de Henares. Pza. San Diego 28801, Alcalá de Henares, Spain.

${ }^{g}$ Dept. of Pharmacology, School of Pharmacy, University Complutense. Avd. Complutense 28040 Madrid, Spain. 
${ }^{\mathrm{h}}$ Schepens Eye Research Institute and Massachusetts Eye and Ear, Dept. of Ophthalmology, Harvard Medical School, Boston, MA, USA 02114.

${ }^{\text {i }}$ CNRS UMR 8612, Université de Paris Sud, Laboratoire de Physicochimie, Pharmacotechnie et Biopharmacie, Faculté de Pharmacie - Université Paris-Sud 5, rue Jean-Baptiste Clément 92296 Châtenay-Malabry, Paris, France.

* Corresponding author. Phone number: +34 913941 737. Fax number: +34 913941 736; e-mail address: ibravo@ucm.es 


\section{Abstract}

Purpose: To determine the potential use of water-soluble anionic and cationic carbosilane dendrimers (Generations 1-3) as mucoadhesive polymers in eyedrop formulations. Methods: Cationic carbosilane dendrimers decorated with ammonium $-\mathrm{NH}_{3}{ }^{+}$groups were prepared by hydrosylilation of Boc-protected allylamine and followed by deprotection with $\mathrm{HCl}$. Anionic carbosilane dendrimers with terminal carboxylate groups were also employed in this study. In vitro and in vivo tolerance studies were performed in human ocular epithelial cell lines and rabbit eyes respectively. The interaction of dendrimers with transmembrane ocular mucins was evaluated with a surface biosensor. As proof of concept, the hypotensive effect of a carbosilane dendrimer eyedrop formulation containing acetazolamide (ACZ), a poorly water-soluble drug with limited ocular penetration, was tested after instillation in normotensive rabbits. Results: The methodology used to synthesize cationic dendrimers avoids the difficulty of obtaining neutral $-\mathrm{NH}_{2}$ dendrimers that require harsher reaction conditions and also present high aggregation tendency. Tolerance studies demonstrated that both prototypes of water-soluble anionic and cationic carbosilane dendrimers were well tolerated in a range of concentrations between 5 and $10 \mu \mathrm{M}$. Permanent interactions between cationic carbosilane dendrimers and ocular mucins were observed using biosensor assays, predominantly for the generation-three (G3) dendrimer. An eyedrop formulation containing G3 cationic carbosilane dendrimers $(5 \mu \mathrm{M})$ and ACZ (0.07\%) (289.4 mOsm; $5.6 \mathrm{pH} ; 41.7 \mathrm{mN} / \mathrm{m})$ induced a rapid (onset time $1 \mathrm{~h})$ and extended (up to $7 \mathrm{~h}$ ) hypotensive effect, and led to a significant increment in the efficacy determined by $\mathrm{AUC}_{0}{ }^{8 \mathrm{~h}}$ and maximal intraocular pressure reduction. Conclusion: This work takes advantage of the high-affinity interaction between cationic carbosilane dendrimers and ocular transmembrane mucins, as well as the tensioactive behavior observed for these polymers. Our results indicate that low amounts of cationic carbosilane dendrimers are well tolerated and able 
to improve the hypotensive effect of an acetazolamide solution. Our results suggest that carbosilane dendrimers can be used in a safe range of concentrations to enhance the bioavailability of drugs topically administered in the eye.

Keywords: Carbosilane dendrimers; ocular transmembrane mucins; mucoadhesion; surface plasmon resonance (SPR); hypotensive activity. 


\section{Introduction}

It is estimated that only about $5 \%$ of any drug administered by the topical ocular route is able to cross the cornea, reaching the anterior segment of the eye. ${ }^{1}$ This makes it necessary to administer multiple doses of the drug per day. Furthermore, a portion of some administered drugs can be absorbed through the nasal and oral mucosa following drainage through the naso-lacrimal duct, and this can result in systemic side effects. One approach to increase ocular drug bioavailability is to maintain the formulation on the ocular surface longer. Classic (linear) bioadhesive polymers such as hyaluronic acid or cellulose derivatives included in eyedrop formulations can increase the drug residence time on the ocular surface. With this strategy, both the systemic drug side effects and the dosing frequency can be reduced., ${ }^{2,3}$ However, discomfort, blurred vision, and the presence of residual material around the eye are typically associated to these viscous media.

Recently, the use of dendritic structures has been explored with the aim of increasing the residence time of drugs on the ocular surface and reducing systemic absorption. For example, several authors have shown that polyamidoamine (PAMAM) dendrimers in solution ${ }^{4}$ or combined with polyethylene glycol as hydrogels ${ }^{5}$ can improve the residence time of several drugs. These dendritic structures can strongly interact with transmembrane ocular mucins, as recently demonstrated by our research group. ${ }^{6}$

The approach presented in this work uses new dendritic structures based on a C-Si backbone (carbosilane dendrimers) as potential bioadhesive polymers to be included in eyedrop formulations. These structures could benefit the administration of very poorly water-soluble drugs on the ocular surface. However, the higher hydrophobicity of carbosilane dendrimers implies that it is necessary to introduce ionic moieties (anionic or cationic groups) to achieve solubility in water. ${ }^{7-9}$ The objective of the present work is the evaluation of Generations 1, 2, and 3 of carbosilane dendrimers, with both anionic and cationic terminal groups, for topical ocular delivery. In an attempt to select the optimal concentration of these structures suitable for eye tissues, we first estimated the in vitro and in vivo tolerance in human 
conjunctival and corneal cell lines and in rabbit eyes. Afterwards, the interaction of carbosilane dendrimers with transmembrane ocular mucin isolates was evaluated by surface plasmon resonance (SPR) spectroscopy. ${ }^{6}$ The most promising candidate was formulated with acetazolamide (ACZ), a hypotensive drug useful in glaucoma treatment after oral administration but which is inadequate for topical application due to low bioavailability after instillation. The eyedrop formulation was characterized and tested in normotensive rabbits.

\section{Materials and Methods}

\section{Materials}

We prepared anionic dendrimers $\mathrm{G}_{\mathrm{n}} \mathrm{Si}\left(\mathrm{CO}_{2}{ }^{-}, \mathrm{Na}^{+}\right)_{\mathrm{m}}(\mathrm{n}=1, \mathrm{~m}=8 ; \mathrm{n}=2, \mathrm{~m}=16 ; \mathrm{n}=3, \mathrm{~m}=32)$ as previously published. ${ }^{9}$ t-butyl $\mathrm{N}$-allylcarbamate $\left(\mathrm{C}_{3} \mathrm{H}_{5} \mathrm{NHBoc}\right.$, Boc protected allylamine), Karstedt's catalyst, and $\mathrm{HCl}\left(\mathrm{Et}_{2} \mathrm{O}\right)$ were purchased from Sigma Chemical Co. (Madrid, Spain) and used as received.

A telomerase-immortalized, human corneal-limbal epithelial cell line (HCLE) was kindly supplied by Prof. I. K. Gipson (Schepens Eye Research Institute, Boston, MA, USA), and the human conjunctival epithelial cell line (IOBA-NHC) was provided by IOBA (Instituto de Oftalmología y Biologia Aplicada, Valladolid, Spain). Reagents for cell cultures were purchased from Gibco ${ }^{\circledR}$ (Life Technologies, Barcelona, Spain). Acetazolamide, sodium chloride, and 3-(4,5-dimethylthiazol-2-Y1)-2,5diphenyltetrazolium bromide (MTT) solution $(5 \mathrm{mg} / \mathrm{mL}$ in phosphate-buffered saline) were obtained from Sigma Chemical Co. (Madrid, Spain). Reagents and materials used for the SPR experiments were obtained from GE Healthcare (Orsay, France). All other chemicals used were reagent grade and used as received.

\section{Animals}

Male New Zealand white rabbits (San Bernardo Farm, Navarra, Spain), weighing 3-3.5 kg, were used for some experiments. The animals were kept in individual cages with free access to food and water. They 
were housed in a room with controlled $12 \mathrm{~h} / 12 \mathrm{~h}$ light/dark cycles and maintained at $22^{\circ} \mathrm{C}$ with $50 \%$ relative humidity. All of the protocols herein complied with the ARVO Statement for the Use of Animals in Ophthalmology and Vision Research and also are in accordance with the European Communities Council Directive (86/609/EEC).

\section{Methods}

\section{Cationic dendrimers: preparation and characterization}

All reactions were carried out under an inert atmosphere, and solvents were purified from appropriate drying agents when necessary. Nuclear magnetic resonance (NMR) spectra were recorded on a Varian Unity VXR-300 $\left(300.13\left({ }^{1} \mathrm{H}\right), 75.47\left({ }^{13} \mathrm{C}\right) \mathrm{MHz}\right)$ or on a Bruker AV400 $\left(400.13(1 \mathrm{H}), 100.60\left({ }^{13} \mathrm{C}\right), 79.49\right.$ $\left.\left({ }^{29} \mathrm{Si}\right) \mathrm{MHz}\right)$. Chemical shifts $(\delta)$ were recorded in parts per million $(\mathrm{ppm}) .{ }^{1} \mathrm{H}$ and ${ }^{13} \mathrm{C}$ resonances were measured relative to internal deuterated solvent peaks considering TMS $=0 \mathrm{ppm} .{ }^{29} \mathrm{Si}$ resonances were measured relative to external TMS. When necessary, assignment of resonances was done from HSQC, HMBC, COSY, TOCSY, and NOESY NMR experiments. Elemental analyses were performed on a LECO CHNS-932 instrument. Mass Spectra were obtained from Bruker Ultraflex III and Agilent 6210 instruments. Starting dendrimers were $\mathrm{G}_{\mathrm{n}} \mathrm{O}_{3}(\mathrm{SiH})_{\mathrm{m}}(\mathrm{n}=1, \mathrm{~m}=6 ; \mathrm{n}=2, \mathrm{~m}=12 ; \mathrm{n}=3, \mathrm{~m}=24)^{10}$.

The synthesis of cationic dendrimers is presented in Scheme 1.

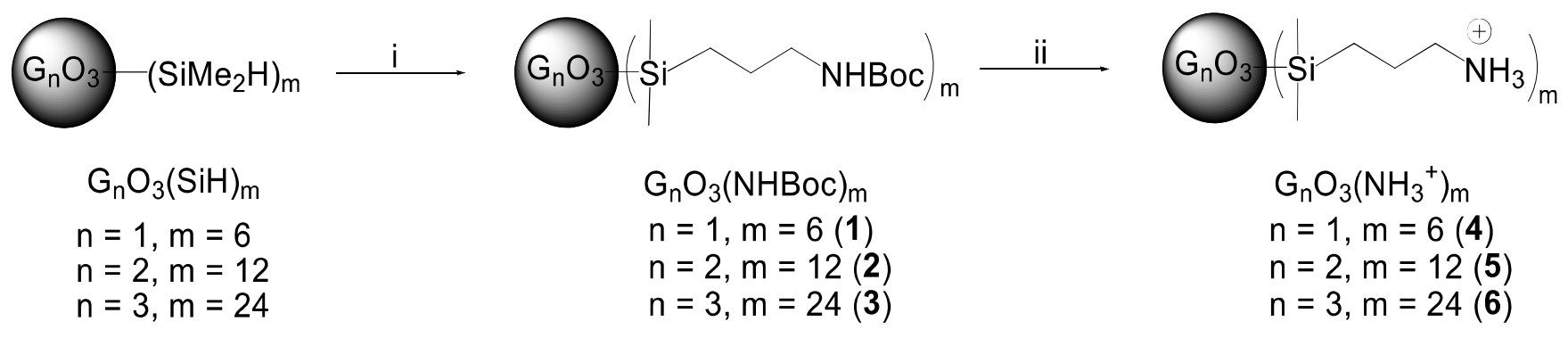

Scheme 1. Synthesis of cationic dendrimers $\mathrm{G}_{\mathrm{n}} \mathrm{O}_{3}\left(\mathrm{NH}_{3}{ }^{+}\right)_{\mathrm{m}}$ (Compounds 4-6). (i) $\mathrm{C}_{3} \mathrm{H}_{5} \mathrm{NHBoc}$, [Pt], $60^{\circ} \mathrm{C}, 14 \mathrm{~h}$; (ii) $\mathrm{HCl}\left(\mathrm{Et}_{2} \mathrm{O}\right)$. 
$\mathbf{G}_{\mathbf{1}} \mathbf{O}_{3}(\mathbf{N H B o c})_{6}\left(\right.$ Compound 1) A solution of $\mathrm{G}_{1} \mathrm{O}_{3}(\mathrm{SiH})_{6}(0.500 \mathrm{~g}, 0.486 \mathrm{mmol}), \mathrm{C}_{3} \mathrm{H}_{5} \mathrm{NHBoc}(0.466$ $\mathrm{g}, 2.966 \mathrm{mmol})$ and Karstedt's catalyst (3\% mol of Si-H bonds) were stirred in dry THF (5 mL) in a Teflon-valved ampoule and heated at $50{ }^{\circ} \mathrm{C}$ for $16 \mathrm{~h}$. Compound $\mathbf{1}$ was purified by size exclusion chromatography in THF. After removal of the solvent, Compound $\mathbf{1}$ was obtained as a pale yellow oil (0.681 g, 71\%). For Compound 1, the NMR data $\left(\delta, \mathrm{CDCl}_{3}\right)$ was as follows: ${ }^{1} \mathrm{H}:-0.09(\mathrm{~s}, 9 \mathrm{H}, \mathrm{MeSi})$, $0.07\left(\mathrm{~s}, 36 \mathrm{H}, \mathrm{Me}_{2} \mathrm{Si}\right), 0.46\left(\mathrm{~m}, 12 \mathrm{H}, \mathrm{SiCH}_{2}\right), 0.53\left(\mathrm{~m}, 30 \mathrm{H}, \mathrm{SiCH} H_{2}\right), 1.25\left(\mathrm{~m}, 18 \mathrm{H}, \mathrm{CH}_{2}\right), 1.42(\mathrm{~m}, 12+$ $54 \mathrm{H}, \mathrm{CH}_{2}$ and $\left.t-\mathrm{Bu}\right), 1.75\left(\mathrm{~m}, 6 \mathrm{H}, \mathrm{OCH}_{2} \mathrm{CH}_{2}\right), 3.05\left(\mathrm{~m}, 12 \mathrm{H}, \mathrm{CH}_{2} \mathrm{~N}\right), 3.87\left(\mathrm{t}, \mathrm{J}=6.3 \mathrm{~Hz}, 6 \mathrm{H}, \mathrm{OCH}_{2}\right)$, 4.56 (bs, $6 \mathrm{H}, \mathrm{NH}), 6.04\left(\mathrm{~s}, 3 \mathrm{H}, \mathrm{C}_{6} \mathrm{H}_{3}\right) ;{ }^{13} \mathrm{C}-\left\{{ }^{1} \mathrm{H}\right\}:-5.1(\mathrm{MeSi}),-3.4\left(\mathrm{Me}_{2} \mathrm{Si}\right), 12.4\left(\mathrm{NCH}_{2} \mathrm{CH}_{2} \mathrm{CH}_{2}\right), 13.8$ $\left(\mathrm{SiCH}_{2}\right), 18.4,18.6,20.0\left(\mathrm{CH}_{2}\right), 20.5\left(\mathrm{OCH}_{2} \mathrm{CH}_{2} \mathrm{CH}_{2}\right), 24.6\left(\mathrm{CH}_{2} \mathrm{CH}_{2} \mathrm{~N}\right), 28.4\left(\mathrm{CMe}_{3}\right), 33.2\left(\mathrm{OCH}_{2} \mathrm{CH}_{2}\right)$, $43.8\left(\mathrm{NCH}_{2}\right), 67.6\left(\mathrm{OCH}_{2}\right), 78.9\left(\mathrm{CMe}_{3}\right), 93.7\left(C_{6} \mathrm{H}_{3}(C \mathrm{H}), 155.9\left(\mathrm{NHCO}_{2}\right), 160.9\left(i-C_{6} \mathrm{H}_{3}\right) ;{ }^{29} \mathrm{Si}: 1.8\right.$ (MeSi), $2.1\left(\mathrm{Me}_{2} \mathrm{Si}\right)$. MS-ESI: $1988.3707\left[\mathrm{M}+\mathrm{NH}_{4}\right]^{+}$. Elemental analysis for $\mathrm{C}_{99} \mathrm{H}_{204} \mathrm{~N}_{6} \mathrm{O}_{15} \mathrm{Si}_{9}$ : Calcd. C, $60.31 ; \mathrm{H}, 10.43 ; \mathrm{N}, 4.26$; Obt. C, 60.78; H, 10.72; N, 4.11.

$\mathbf{G}_{\mathbf{2}} \mathbf{O}_{3}(\mathbf{N H B o c})_{\mathbf{1 2}}\left(\right.$ Compound 2) Following the above procedure, starting from $\mathrm{G}_{2} \mathrm{O}_{3}(\mathrm{SiH})_{12}(0.450 \mathrm{~g}$, $0.210 \mathrm{mmol}), \mathrm{C}_{3} \mathrm{H}_{5} \mathrm{NHBoc}(0.400 \mathrm{~g}, 2.536 \mathrm{mmol})$, and Karstedt's catalyst, but washing with n-hexane after removal of volatiles, compound 2 was obtained as a pale yellow oil (0.668 g, 79\%). For Compound 2, the $\operatorname{NMR}\left(\delta, \mathrm{CDCl}_{3}\right)$ was as follows: ${ }^{1} \mathrm{H}:-0.11(\mathrm{~s}, 27 \mathrm{H}, \mathrm{MeSi}),-0.07\left(\mathrm{~s}, 72 \mathrm{H}, \mathrm{Me}_{2} \mathrm{Si}\right), 0.43(\mathrm{~m}, 26 \mathrm{H}$, $\left.\mathrm{CH}_{2} \mathrm{Si}\right), 0.53\left(\mathrm{~m}, 72 \mathrm{H}, \mathrm{CH}_{2} \mathrm{Si}\right), 1.27\left(\mathrm{~s}, 24 \mathrm{H}, \mathrm{CH}_{2}\right), 1.42\left(\mathrm{~m}, 24+108 \mathrm{H}, \mathrm{CH}_{2}\right.$ and $\left.t-B u\right), 1.77(\mathrm{~m}, 6 \mathrm{H}$, $\left.\mathrm{OCH}_{2} \mathrm{CH}_{2}\right), 3.05\left(\mathrm{~m}, 24 \mathrm{H}, \mathrm{CH}_{2} \mathrm{~N}\right), 3.86\left(\mathrm{~m}, 6 \mathrm{H}, \mathrm{OCH}_{2}\right), 4.59(\mathrm{bs}, 12 \mathrm{H}, \mathrm{NH}), 6.04\left(\mathrm{~s}, 3 \mathrm{H}, \mathrm{C}_{6} H_{3}\right) ;{ }^{13} \mathrm{C}-$ $\left\{{ }^{1} \mathrm{H}\right\}:-4.9(\mathrm{MeSi}),-4.7(\mathrm{MeSi}),-3.3\left(\mathrm{Me}_{2} \mathrm{Si}\right), 12.3\left(\mathrm{SiCH}_{2}\right), 13.8\left(\mathrm{SiCH}_{2}\right), 18.4,18.6,18.8,20.0,20.1$ $\left(\mathrm{CH}_{2}\right), 20.6\left(\mathrm{OCH}_{2} \mathrm{CH}_{2} \mathrm{CH}_{2}\right), 24.6\left(\mathrm{CH}_{2} \mathrm{CH}_{2} \mathrm{~N}\right), 28.4\left(\mathrm{CMe}_{3}\right), 33.3\left(\mathrm{OCH}_{2} \mathrm{CH}_{2}\right), 43.6\left(\mathrm{NCH}_{2}\right), 67.6$ $\left(\mathrm{OCH}_{2}\right), 78.9\left(\mathrm{CMe}_{3}\right), 93.7\left(\mathrm{C}_{6} \mathrm{H}_{3}(\mathrm{CH}), 155.8\left(\mathrm{NHCO}_{2}\right), 160.9\left(\mathrm{i}-C_{6} \mathrm{H}_{3}\right) ;{ }^{29} \mathrm{Si}: 0.9(\mathrm{MeSi}), 1.8(\mathrm{Me} S i), 2.0\right.$ $\left(\mathrm{Me}_{2} \mathrm{Si}\right.$ ). Elemental Analysis for $\mathrm{C}_{201} \mathrm{H}_{426} \mathrm{~N}_{12} \mathrm{O}_{27} \mathrm{Si}_{21}$ : Calcd. C, 59.85; H, 10.65; N, 4.17; Obt. C, 60.15; H, $10.99 ; \mathrm{N}, 4.03$. 
$\mathbf{G}_{\mathbf{3}} \mathbf{O}_{\mathbf{3}}(\mathrm{NHBoc})_{\mathbf{2}}$ (Compound 3) Following the procedure described for Compound 2, starting from $\mathrm{G}_{3} \mathrm{O}_{3}(\mathrm{SiH})_{24}(0.450 \mathrm{~g}, 0.103 \mathrm{mmol}), \mathrm{C}_{3} \mathrm{H}_{5} \mathrm{NHBoc}(0.390 \mathrm{~g}, 2.474 \mathrm{mmol})$, and Karstedt's catalyst, Compound 3 was obtained as a pale yellow oil $(0.728 \mathrm{~g}, 87 \%)$. For $\mathrm{G} 3$, the $\mathrm{NMR}\left(\delta, \mathrm{CDCl}_{3}\right)$ data were as follows: ${ }^{1} \mathrm{H}$ : -0.11 (s, $\left.54 \mathrm{H}, \mathrm{MeSi}\right),-0.07$ (s, $\left.144 \mathrm{H}, \mathrm{Me}_{2} \mathrm{Si}\right), 0.45$ (m, $48 \mathrm{H}, \mathrm{SiCH}_{2}$ ), 0.52 (m, $174 \mathrm{H}$, $\left.\mathrm{SiCH}_{2}\right), 1.27\left(\mathrm{~s}, 48 \mathrm{H}, \mathrm{CH}_{2}\right), 1.42\left(\mathrm{~m}, 48+216 \mathrm{H}, \mathrm{CH}_{2}\right.$ and $\left.t-\mathrm{Bu}\right), 1.77\left(\mathrm{~m}, 6 \mathrm{H}, \mathrm{OCH}_{2} \mathrm{CH}_{2}\right), 3.05(\mathrm{~m}, 24$ $\left.\mathrm{H}, \mathrm{CH}_{2} \mathrm{~N}\right), 3.84\left(\mathrm{~m}, 6 \mathrm{H}, \mathrm{OCH}_{2}\right), 4.63(\mathrm{bs}, 12 \mathrm{H}, \mathrm{NH}), 6.01\left(\mathrm{~s}, 3 \mathrm{H}, \mathrm{C}_{6} H_{3}\right) ;{ }^{13} \mathrm{C}-\left\{{ }^{1} \mathrm{H}\right\}:-4.9(\mathrm{MeSi}),-3.3$ $\left(M e_{2} \mathrm{Si}\right), 12.8\left(\mathrm{CH}_{2} \mathrm{CH}_{2} \mathrm{CH}_{2} \mathrm{~N}\right), 14.1\left(\mathrm{SiCH}_{2}\right), 17.9-20.6\left(\mathrm{CH}_{2}\right), 24.6\left(\mathrm{CH}_{2} \mathrm{CH}_{2} \mathrm{~N}\right), 28.4\left(\mathrm{CMe}_{3}\right), 33.4$ $\left(\mathrm{OCH}_{2} \mathrm{CH}_{2}\right), 43.8\left(\mathrm{CH}_{2} \mathrm{~N}\right), 67.8\left(\mathrm{OCH}_{2}\right), 78.9\left(\mathrm{CMe}_{3}\right), 93.7\left(\mathrm{C}_{6} \mathrm{H}_{3}(\mathrm{CH}), 155.9\left(\mathrm{NHCO}_{2}\right), 160.9\left(\mathrm{i}-C_{6} \mathrm{H}_{3}\right)\right.$; ${ }^{29} \mathrm{Si}: 0.9(\mathrm{MeSi}), 1.8(\mathrm{MeSi}), 2.1\left(\mathrm{Me}_{2} \mathrm{Si}\right)$. Elemental Analysis for $\mathrm{C}_{405} \mathrm{H}_{870} \mathrm{~N}_{24} \mathrm{O}_{51} \mathrm{Si}_{45}$ : Calc. C, 59.63; H, $10.75 ; \mathrm{N}, 4.12$; Obt. C, 59.00; H, 10.38; N, 3.09 .

$\mathbf{G}_{1} \mathbf{O}_{3}\left(\mathbf{N H}_{3} \mathbf{C l}\right)_{6}$ (Compound 4) A solution of Compound 1 (0.200 g, $\left.0.100 \mathrm{mmol}\right)$ in THF (10 mL) was treated with $\mathrm{HCl}\left(6.0 \mathrm{~mL}, 1 \mathrm{M}\right.$ in $\left.\mathrm{Et}_{2} \mathrm{O}\right)$ and stirred for $1 \mathrm{~h}$. Afterward, the solution was filtered off and the residue was washed with $\mathrm{Et}_{2} \mathrm{O}(2 \times 25 \mathrm{~mL})$ and dried, obtaining Compound 4 as a white solid $(0.136 \mathrm{~g}, 85 \%)$. For Compound 4 , the NMR $\left(\delta, \mathrm{D}_{2} \mathrm{O}\right)$ data were as follows: ${ }^{1} \mathrm{H}:-0.21(\mathrm{~s}, 9 \mathrm{H}, \mathrm{MeSi}),-0.11$ (s, $\left.36 \mathrm{H}, \mathrm{Me}_{2} \mathrm{Si}\right), 0.44\left(\mathrm{~s}, 42 \mathrm{H}, \mathrm{CH}_{2} \mathrm{Si}\right), 1.24\left(\mathrm{~s}, 18 \mathrm{H}, \mathrm{CH}_{2}\right), 1.55\left(\mathrm{~s}, 12 \mathrm{H}, \mathrm{CH}_{2}\right), \mathrm{OCH}_{2} \mathrm{CH}_{2}$ not observed, $2.80\left(\mathrm{~s}, 12 \mathrm{H}, \mathrm{CH}_{2} \mathrm{~N}\right), 3.55\left(\mathrm{bs}, 6 \mathrm{H}, \mathrm{OCH}_{2}\right), 5.69$ (bs, $\left.3 \mathrm{H}, \mathrm{C}_{6} \mathrm{H}_{3}\right) ;{ }^{13} \mathrm{C}-\left\{{ }^{1} \mathrm{H}\right\}:-5.4(\mathrm{MeSi}),-3.9\left(\mathrm{Me}_{2} \mathrm{Si}\right)$, $11.1\left(\mathrm{NCH}_{2} \mathrm{CH}_{2} \mathrm{CH}_{2}\right), \quad 12.9\left(\mathrm{SiCH}_{2}\right), \quad 18.4, \quad 18.6,20.0,21.1\left(\mathrm{CH}_{2}\right), 22.1 \quad\left(\mathrm{OCH}_{2} \mathrm{CH}_{2} \mathrm{CH}_{2}\right), \quad 31.9$ $\left(\mathrm{OCH}_{2} \mathrm{CH}_{2}\right), 48.0\left(\mathrm{NCH}_{2}\right), 66.6\left(\mathrm{OCH}_{2}\right), 93.1\left(\mathrm{C}_{6} \mathrm{H}_{3}(\mathrm{CH}), 160.0\left(i-C_{6} \mathrm{H}_{3}\right) ;{ }^{29} \mathrm{Si}: 1.9(\mathrm{MeSi}), 2.2\left(\mathrm{Me}_{2} \mathrm{Si}\right)\right.$. Elemental Analysis for $\mathrm{C}_{69} \mathrm{H}_{162} \mathrm{Cl}_{6} \mathrm{~N}_{6} \mathrm{O}_{3} \mathrm{Si}_{9}$ : Calc. C, 52.14; H, 10.27; N, 5.29; Obt. C, 53.01; H, 10.91; N, 5.10 .

$\mathbf{G}_{\mathbf{2}} \mathbf{O}_{3}\left(\mathbf{N H}_{3} \mathbf{C l}\right)_{12}$ (Compound 5) Following the above procedure, starting from Compound 2 (0.200 g, $0.050 \mathrm{mmol})$ and $\mathrm{HCl}\left(12.0 \mathrm{~mL}, 1 \mathrm{M}\right.$ in $\left.\mathrm{Et}_{2} \mathrm{O}\right)$ and stirring for $2 \mathrm{~h}$, Compound 5 was obtained as a white solid $(0.132 \mathrm{~g}, 82 \%)$. For Compound 5, the $\mathrm{NMR}\left(\delta, \mathrm{D}_{2} \mathrm{O}\right)$ data were as follows: ${ }^{1} \mathrm{H}:-0.18(\mathrm{~s}, 99 \mathrm{H}, \mathrm{MeSi}$ and $\mathrm{Me}_{2} \mathrm{Si}$ ), $0.44\left(\mathrm{~s}, 102 \mathrm{H}, \mathrm{CH}_{2} \mathrm{Si}\right), 1.24\left(\mathrm{~s}, 72 \mathrm{H}, \mathrm{CH}_{2}\right), 1.55$ (s, $\left.24 \mathrm{H}, \mathrm{CH}_{2}\right), \mathrm{OCH}_{2} \mathrm{CH}_{2}$ not observed, 
$2.81\left(\mathrm{~s}, 24 \mathrm{H}, \mathrm{CH}_{2} \mathrm{~N}\right), 3.55\left(\mathrm{bs}, 6 \mathrm{H}, \mathrm{OCH}_{2}\right), 5.69\left(\mathrm{bs}, 3 \mathrm{H}, \mathrm{C}_{6} \mathrm{H}_{3}\right) ;{ }^{13} \mathrm{C}-\left\{{ }^{1} \mathrm{H}\right\}:-5.4(\mathrm{MeSi}),-3.9\left(\mathrm{Me}_{2} \mathrm{Si}\right)$, $11.2\left(\mathrm{NCH}_{2} \mathrm{CH}_{2} \mathrm{CH}_{2}\right), 12.9\left(\mathrm{SiCH}_{2}\right), 17.7,18.8,21.1\left(\mathrm{CH}_{2}\right), 22.1\left(\mathrm{OCH}_{2} \mathrm{CH}_{2} \mathrm{CH}_{2}\right), 31.5\left(\mathrm{OCH}_{2} \mathrm{CH}_{2}\right), 48.0$ $\left(\mathrm{NCH}_{2}\right), 66.6\left(\mathrm{OCH}_{2}\right), 93.1\left(\mathrm{C}_{6} \mathrm{H}_{3}(\mathrm{CH}), 159.8\left(i-C_{6} \mathrm{H}_{3}\right) ;{ }^{29} \mathrm{Si}: 1.0\right.$ and $1.7(\mathrm{MeSi}), 2.1\left(\mathrm{Me}_{2} \mathrm{Si}\right)$. Elemental Analysis for $\mathrm{C}_{141} \mathrm{H}_{342} \mathrm{Cl}_{12} \mathrm{~N}_{12} \mathrm{O}_{3} \mathrm{Si}_{21}$ : Calc. C, 51.80; H, 10.54; N, 5.14; Obt. C, 51.21; H, 10.17; N, 4.83.

$\mathbf{G}_{3} \mathbf{O}_{3}\left(\mathrm{NH}_{3} \mathbf{C l}\right)_{24}$ (Compound 6). Following the above procedure, starting from Compound 3 (0.200 g, $0.024 \mathrm{mmol})$ and $\mathrm{HCl}\left(12.0 \mathrm{~mL}, 1 \mathrm{M}\right.$ in $\left.\mathrm{Et}_{2} \mathrm{O}\right)$ and stirring for $2 \mathrm{~h}$, Compound 6 was obtained as a white solid $(0.134 \mathrm{~g}, 83 \%)$. For Compound 6, the NMR $\left(\delta, \mathrm{D}_{2} \mathrm{O}\right)$ data were as follows: ${ }^{1} \mathrm{H}:-0.16(\mathrm{~s}, 63 \mathrm{H}$, $\mathrm{MeSi}$ ), and $\mathrm{Me}_{2} \mathrm{Si}$ ), 0.49 (bm, $270 \mathrm{H}, \mathrm{CH}_{2} \mathrm{Si}$ ), 1.29 (s, $138 \mathrm{H}, \mathrm{CH}_{2}$ ), 1.55 (s, $48 \mathrm{H}, \mathrm{CH}_{2}$ ), $\mathrm{OCH}_{2} \mathrm{CH}_{2}$ not observed, $2.86\left(\mathrm{~s}, 48 \mathrm{H}, \mathrm{CH} \mathrm{H}_{2} \mathrm{~N}\right), \mathrm{OCH}_{2}$ not observed, $\mathrm{C}_{6} \mathrm{H}_{3}$ not observed; ${ }^{13} \mathrm{C}-\left\{{ }^{1} \mathrm{H}\right\}:-4.4(\mathrm{MeSi}),-3.0$ $\left(\mathrm{Me}_{2} \mathrm{Si}\right), 12.2\left(\mathrm{NCH}_{2} \mathrm{CH}_{2} \mathrm{CH}_{2}\right), 18.0-18.8,19.9\left(\mathrm{CH}_{2}\right), \mathrm{OCH}_{2} \mathrm{CH}_{2} \mathrm{CH}_{2}$ not observed, $\mathrm{OCH}_{2} \mathrm{CH}_{2}$ not observed, $48.0\left(\mathrm{NCH}_{2}\right), \mathrm{OCH}_{2}$ not observed, $C_{6} \mathrm{H}_{3}$ not observed, $i-C_{6} \mathrm{H}_{3}$ not observed; ${ }^{29} \mathrm{Si}: 1.1(\mathrm{MeSi})$, $2.1\left(\mathrm{Me}_{2} \mathrm{Si}\right)$. Elemental Analysis for $\mathrm{C}_{285} \mathrm{H}_{702} \mathrm{Cl}_{24} \mathrm{~N}_{24} \mathrm{O}_{3} \mathrm{Si}_{45}$ : Calc. C, 51.63; H, 10.67; N, 5.07; Obt. C, $51.01 ; \mathrm{H}, 10.12 ; \mathrm{N}, 4.67$.

Carbosilane dendrimers of Generations 1 to 3 , both anionic and cationic, were dissolved in $\mathrm{NaCl}$ $0.9 \%$ media prior to characterization. For simplicity, the nomenclature employed for dendrimers described in the remainder of this paper will be of the type "Gn-A" (for anionic dendrimers) or "Gn-C" (for cationic dendrimers), where "Gn" indicates the generation.

\section{Tolerance studies}

In vitro experiments The cytotoxicity of saline solutions of $\mathrm{C}$-Si anionic and cationic dendrimers G1-3 was assessed by the mitochondrial-dependent reduction of the tetrazolium salt (3-(4,5-dimethylthiazol-2yl)-2,5-diphenyltetrazolium bromide) to formazan (MTT method) according to previous works. ${ }^{3}$ The cytotoxicity studies were performed on immortalized human corneal-limbal epithelial (HCLE) cells, generously donated by Dr. Ilene K. Gipson (Schepens Eye Research Institute, Harvard Medical School, 
Boston, MA, USA) and normal human conjunctiva (IOBA-NHC) cells generously donated by the Institute for Applied Ophthalmobiology (University of Valladolid, Valladolid, Spain).

HCLE cells and IOBA cells were seeded into 96-well culture plates (40,000 cells/well) and cultured at $37^{\circ} \mathrm{C}$ for $24 \mathrm{~h}$ in a $5 \% \mathrm{CO}_{2}$ atmosphere. Adherent cells were exposed to dendrimer solutions for $15 \mathrm{~min}$ (short-term), $1 \mathrm{~h}$ (intermediate-term), or $4 \mathrm{~h}$ (long-term). These times were chosen to emulate the types of dwell times on the ocular surface of various formulations. An isotonic $\mathrm{NaCl}$ solution with $0.005 \%$ benzalkonium chloride was used as a positive control.

Cell viability was determined by the mitochondrial reduction of MTT to formazan. The cells were incubated in a MTT solution ( $5 \mathrm{mg} / \mathrm{mL}$ in phosphate-buffered saline) for $3 \mathrm{~h}$ at $37^{\circ} \mathrm{C}$. After careful aspiration of the MTT solution, the cells were solubilized with dimethyl sulfoxide (100 $\mu \mathrm{L} /$ well $)$. The extent of the reduction of MTT to formazan by the cells was quantified by optical density measurements at $550 \mathrm{~nm}$ using a plate reader (Digiscan mod 6010152EU, Eugendorf, Austria). Viability was set as $100 \%$ in untreated cells. Eight wells per sample were tested, and the assays were performed in triplicate. The results were expressed as the reduction in cellular viability compared to negative controls for at least three independent experiments.

In vivo experiments The in vivo ocular tolerance studies of saline solutions containing C-Si anionic and cationic dendrimers G1-3 were performed by instillation of $25 \mu \mathrm{L}$ of each solution onto the right eye in five male New Zealand albino rabbits. The contralateral eye received the same volume of saline solution (control). Examination of the eyes was performed by specular microscopy before instillation of any substance, just after instillation, and at two and six hours post-instillation. A slit lamp (SL-8Z, Topcon, Barcelona, Spain) was used to evaluate pupillary reflex, pupil size, superior and inferior eyelids, presence of redness, blepharitis and blepharospasm, tear charge, exudates, fluorescein tear film break up time (TBUT), redness of bulbar, limbal and tarsal conjunctival surfaces, inflammation of nictitating 
membrane, and transparency of the cornea. ${ }^{11}$ Ocular signs were graded using the Efron scale $(0=$ normal; $1=\operatorname{trace} ; 2=$ mild $; 3=$ moderate $; 4=$ severe $)^{12}$

\section{Mucoadhesion studies}

After the tolerance studies, the interaction of selected concentrations of $\mathrm{C}-\mathrm{Si}$ anionic and cationic dendrimers G1-3 with transmembrane ocular mucins was analyzed by SPR spectroscopy (Biacore ${ }^{\circledR}$ T100 GE Healthcare, Orsay, France). One substance, the ligand, is attached on the surface of a sensor chip. The second product, the analyte, is then pumped across the surface via a microfluidic system. If interaction between the ligand and the analyte occurs, the refractive index at the surface of the chip changes and is registered "on line" as an increase in signal.

Mucin isolation The isolation of transmembrane mucin from cultured HCLE cells has been previously described. ${ }^{6}$ Briefly, mucin was purified from stratified HCLE cultures by gel chromatography on a Sepharose CL-4B size exclusion column. The void volume containing the mucin fraction was digested with RNase A and DNase I and further purified by isopycnic density gradient centrifugation in cesium chloride.

Mucin immobilization In a preliminary step, the transmembrane ocular mucin isolates were immobilized on the Sia Kit Au chips $\left(\right.$ Biacore $^{\circledR}$ ) by incubation of the chip surface with $50 \mu \mathrm{L}$ of the transmembrane mucin solution isolated as described above $(80 \mu \mathrm{g} / \mathrm{mL})$ overnight at room temperature. Afterwards, the chips were intensively rinsed in MilliQ ${ }^{\circledR}$ water. Once each chip was prepared and inserted on the Biacore ${ }^{\circledR}$ T100 apparatus, it was again extensively washed with MilliQ ${ }^{\circledR}$ water at $30 \mu \mathrm{L} / \mathrm{min}$ for 12 h. Resonance units (RU) were measured before and after the immobilization step to monitor the amount of mucin attached to the Au chips. Calculations of immobilized mucin amounts were performed on the basis of the Biacore ${ }^{\circledR}$ standards where $1 \mathrm{RU}=1 \mathrm{pg} / \mathrm{mm}^{2}$. The optical mucin layer was calculated considering that $1 \mathrm{RU}$ corresponds to a resonance angle shift of $10^{-4}$ degrees. $^{13}$ 
Binding experiments Binding experiments were performed by flowing saline solutions of G1, G2, and G3 of C-Si anionic and cationic dendrimers ( 5 or10 $\mu \mathrm{M})$ over the mucin coated sensor chip surface within the Biacore ${ }^{\circledR}$ T100 apparatus for $300 \mathrm{~s}$ at $10 \mu \mathrm{L} / \mathrm{min}$. After this contact step, the sensorgram (RU versus time) was collected until equilibrium was reached using physiological saline solution as the running medium control. All studies were performed in triplicate at $35^{\circ} \mathrm{C}$, the physiological ocular surface temperature. $^{14}$

Results were statistically analyzed by one-way analysis of variance (ANOVA) using SPSS version 16.0 software. Post-ANOVA analyses were carried out according to the Bonferroni's multiple comparisons test. Results were considered significant when $\mathrm{p}<0.05$.

\section{Efficacy studies}

\section{Acetazolamide formulations: Preparation and characterization}

Acetazolamide formulations were prepared according to the following procedures:

Formulation 1 (F1): ACZ 0.07\% in saline solution A saturated solution of ACZ was prepared by dissolving $3.5 \mathrm{mg}$ of the drug in $5 \mathrm{~mL}$ of $0.9 \%$ saline. The solution was stirred overnight at $30^{\circ} \mathrm{C}$ to ensure total dissolution.

Formulation 2 (F2): ACZ 0.07\% in saline solution including $5 \mu M$ of G3-C carbosilane dendrimer A saturated solution of $\mathrm{ACZ}$ was prepared by dissolving $3.5 \mathrm{mg}$ of the drug in $5 \mathrm{~mL}$ of $0.9 \%$ saline containing $5 \mu \mathrm{M}$ of G3 cationic carbosilane. The solution was stirred overnight at $30^{\circ} \mathrm{C}$ to ensure total dissolution.

Both formulations and the saline solution $(0.9 \%)$ were characterized in terms of surface tension, $\mathrm{pH}$, and osmolarity. The $\mathrm{pH}$ measurements were performed at room temperature $\left(25^{\circ} \mathrm{C}\right)$ with a $\mathrm{pH}$-meter (model 230, Mettler, Barcelona, Spain) equipped with a microelectrode (InLab, Mettler). Osmolarity of the formulations and vehicle was measured with a Knauer vapor osmometer K-7000 (Knauer GmbH, Berlin, Germany). As a reference, a standard 400 mOsm solution of sodium chloride was used. 
Determinations were performed at $33-35^{\circ} \mathrm{C}$ in triplicate. Surface tension of each formulation was determined by the Whilelmy plate method (PL21; Krüss, Hamburg, Germany), with a digital tensiometer (model K11; Krüss, Hamburg, Germany) in combination with the integrated software (Laboratory Desktop software, ver. 3.11; Krüss, Hamburg, Germany) at $33-35^{\circ} \mathrm{C}$. Before each measurement, the tensiometer was calibrated with MilliQ ${ }^{\circledR}$ water $(72.0 \pm 0.5 \mathrm{mN} / \mathrm{m})$. The time required for equilibration of the formulations was set to 3 minutes. The formulations were assayed in triplicate, with three measurements for each replicate.

\section{Intraocular pressure measurements}

Intraocular pressure (IOP) was measured with a rebound tonometer (Icare Tonovet; Vantaa, Finland). For all of the preparations tested, the instillation volume was $25 \mu \mathrm{L}$. Four animal groups were used for administration of Formulation 1 (18 right eyes), Formulation 2 (18 right eyes), saline solution $0.9 \%$ (10 right eyes), and saline solution $0.9 \%$ containing $5 \mu \mathrm{M}$ of G3-C cationic carbosilane dendrimer (10 right eyes). To study the time-course of the effect of F1 and F2, two IOP measurements were taken before any compound was administered (30 minutes and just before the instillation). Then, measurements were taken once every hour over a period of 8 hours.

The effect of each formulation was defined in terms of IOP reduction $(\Delta \mathrm{IOP})$. It was calculated using as reference the IOP basal (\%) data determined before any instillation in both eyes for each rabbit. Data thus obtained underwent area under the curve-time curve (AUC, \%, per hour) analysis according to the trapezoidal rule.

Data were expressed as the means \pm standard errors of the mean. Statistical differences between the compared values were evaluated by two-tailed student's t-test. P-values less than 0.05 were considered significant.

For efficacy studies, a comparison of the confidence interval was performed for several activity parameters: maximal IOP reduction and area under the curve of the IOP variation versus time plot. 
Differences in the efficacy treatment between F1 and F2 were considered significant when the two-sided $95 \%$ confidence interval for the difference between the means of the selected parameters excluded zero. ${ }^{14}$

\section{Results}

\section{Carbosilane dendrimers}

Formation of cationic carbosilane dendrimers with $-\mathrm{NH}_{3}{ }^{+}$moieties at the periphery can be achieved by protonation of neutral primary amine dendrimers. ${ }^{7,10}$ However, the synthesis of these amine derivatives requires harsh reaction conditions, and the amine dendrimers also have a high aggregation tendency, making storage and manipulation difficult. Furthermore, allylamine is a highly toxic and volatile liquid. For that reason, we used a different approach to obtain cationic carbosilane dendrimers.

First, neutral dendrimers were prepared with primary amino groups protected with Boc, $\mathrm{G}_{\mathrm{n}} \mathrm{O}_{3}(\mathrm{NHBoc})_{\mathrm{m}}[\mathrm{n}=1, \mathrm{~m}=6($ Compound 1); $\mathrm{n}=2, \mathrm{~m}=12($ Compound 2$) ; \mathrm{n}=3, \mathrm{~m}=24($ Compound 3) $]$ (Scheme 1). These compounds were obtained by a simple hydrosilylation reaction of commercially available $\mathrm{C}_{3} \mathrm{H}_{5} \mathrm{NHBoc}$. This material is a solid that is clearly lesser toxic than allylamine, and it has dendrimers that can be decorated with $\mathrm{Si}-\mathrm{H}$ terminal bonds following a procedure similar to that described for related carbosilane dendrons. ${ }^{15}$ The neutral dendrimers thus obtained can be easily stored even in the absence of solvents. NMR spectroscopy showed the disappearance of resonances corresponding to the starting $\mathrm{SiMe}_{2} \mathrm{H}$ functions and the presence of the new groups. The new alkyl chainformed $\mathrm{Si}\left(\mathrm{CH}_{2}\right)_{3} \mathrm{~N}$ was detected by TOCSY-NMR spectroscopy, observing the three methylene groups as multiplets at about $3.0 \mathrm{ppm}\left(\mathrm{CH}_{2} \mathrm{~N}\right), 1.4$ (internal $\left.\mathrm{CH}_{2}\right)$, and $0.5\left(\mathrm{CH}_{2} \mathrm{Si}\right)$. By ${ }^{13} \mathrm{C} \mathrm{NMR}$ spectroscopy, ${ }^{13} \mathrm{C}$ was found at about $44 \mathrm{ppm}$. Also, the carbonyl carbon atom was present at about $156 \mathrm{ppm}$. Finally, in the

${ }^{29} \mathrm{Si}$ NMR spectra, the outermost silicon atom was present at about $2.3 \mathrm{ppm}$, whereas the initial $\mathrm{SiH}$ resonance was observed at about -14 ppm. 


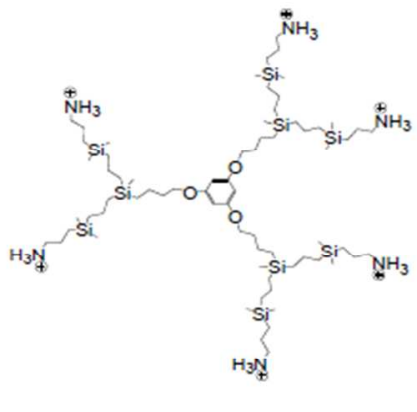

$4(\mathrm{G1}-\mathrm{C})$

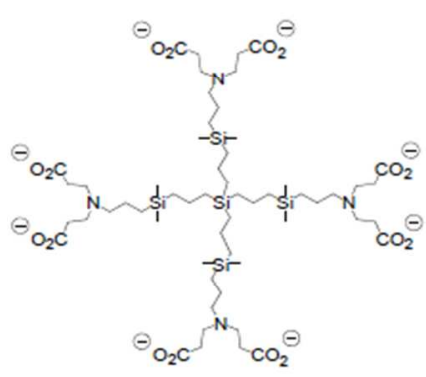

(G1-A)
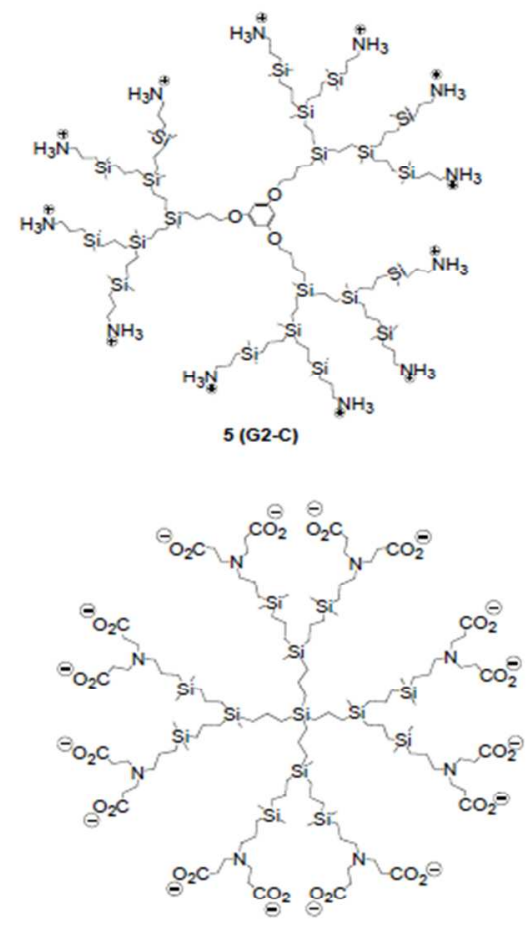

(G2-A)
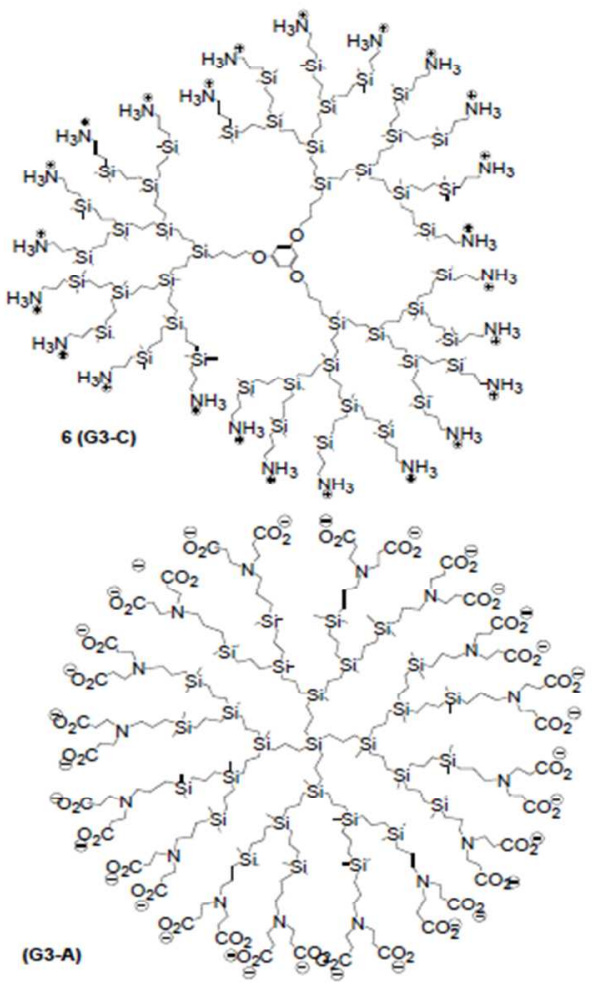

Figure 1: Drawing of cationic Gn-C (Compounds 4-6) and anionic dendrimers Gn-A used in this work

After formation of the cationic carbosilane dendrimers, deprotection of primary amines was successfully performed by addition of excess $\mathrm{HCl}$, isolating the new cationic derivatives $\mathrm{G}_{\mathrm{n}} \mathrm{O}_{3}\left(\mathrm{NH}_{3}{ }^{+}\right)_{\mathrm{m}}[\mathrm{n}$ $=1, \mathrm{~m}=6($ Compound 4$) ; \mathrm{n}=2, \mathrm{~m}=12($ Compound 5); $\mathrm{n}=3, \mathrm{~m}=24($ Compound 6)$)$ (denoted as G1-C, G2-C and G3-C in this paper) (Scheme 1). These derivatives appeared as white solids that were soluble in water, $\mathrm{DMSO}$, and $\mathrm{MeOH}$. In these compounds, the main $\mathrm{NMR}$ resonance belonged to the $\mathrm{CH}_{2} \mathrm{~N}$ groups, observed at about $2.80 \mathrm{ppm}$ in the ${ }^{1} \mathrm{H}$ NMR spectra and at about $48.0 \mathrm{ppm}$ in the ${ }^{13} \mathrm{C}$ NMR spectra. The final structures are presented in Figure 1.

\section{In vitro tolerance studies}


The exposure of HCLE and IOBA-NHC cultures to the anionic and cationic C-Si dendrimers for 15 minutes was intended to mimic a single drop administration to the ocular surface. Exposures for 1 and $4 \mathrm{~h}$ were designed to simulate repeated exposures to the ocular surface.

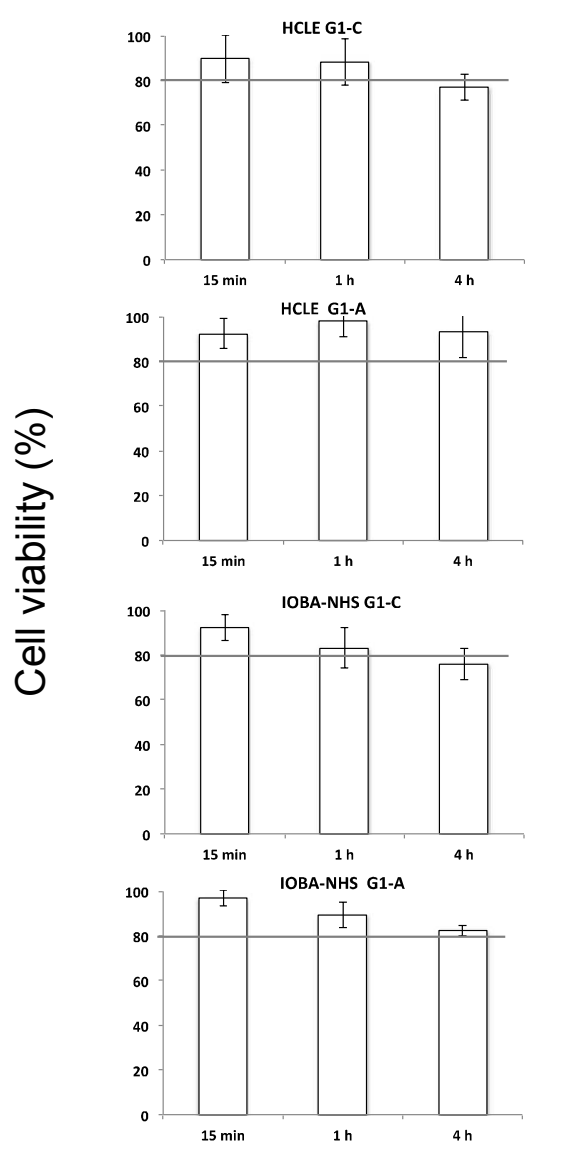

Figure 2
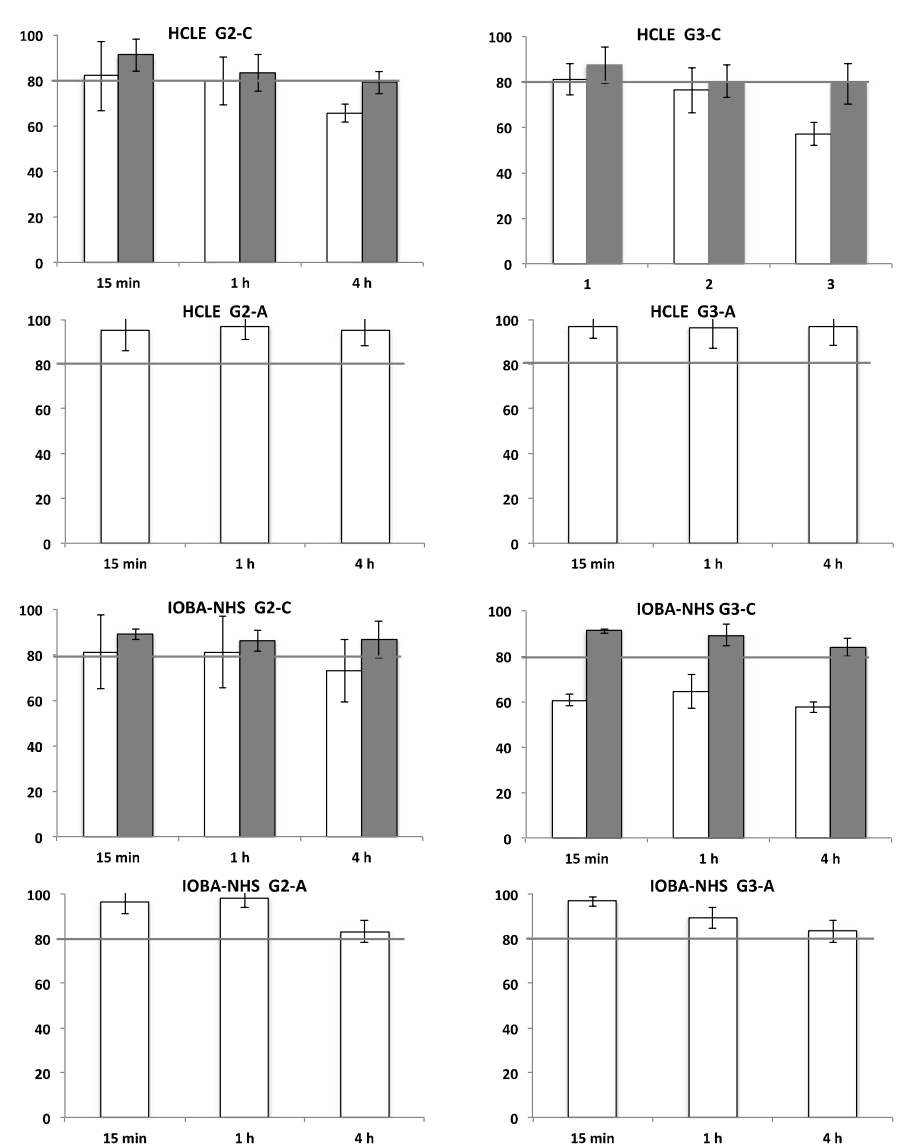

Contact time

Figure 2: In vitro tolerance of the HCLE and IOBA-NHC cell lines to cationic and anionic C-Si dendrimers (Gn-C and Gn-A) in saline solution. White bars, $10 \mu \mathrm{M}$; grey bars, $5 \mu \mathrm{M}$; n, generation number.

All three generations of the anionic dendrimers and generations 1 and 2 of the cationic dendrimers were well tolerated at $10 \mu \mathrm{M}$ (Figure 2). The compounds with percentages of cell survival higher than $80 \%$ relative to non-treated cultures of both cell lines were further evaluated. For the third generation of 
carbosilane cationic dendrimers, G3-C, it was necessary to reduce the concentration to $5 \mu \mathrm{M}$ to obtain non-toxic solutions.

\section{In vivo tolerance studies}

At 5 and $10 \mu \mathrm{M}$, the evaluated carbosilane dendrimer solutions presented neither discomfort nor abnormal clinical signs after topical administration in rabbit eyes (Table 1). The Efron scale scores ranged from $0-2$ in all cases.

Table 1: In vivo tolerance studies in albino rabbit eyes after instillation of $25 \mu \mathrm{L}$ saline solutions of C-Si dendrimers of generation G1, G2, and G3 bearing anionic or cationic surface groups.

\begin{tabular}{|c|c|c|c|c|c|}
\hline \multicolumn{6}{|c|}{ Before instillation } \\
\hline & & & Limbal & Tarsal & \\
\hline Preparation & Tearing & Blepharospasm & Conjunctiva* & Conjunctiva* & Cornea* \\
\hline G1A $(10 \mu M)$ & No & No & $1-2$ & $0-1$ & 1 \\
\hline G2A $(10 \mu M)$ & No & No & $1-2$ & $0-1$ & 1 \\
\hline G3A $(10 \mu M)$ & No & No & $1-2$ & 1 & 1 \\
\hline G1C (10 $\mu \mathrm{M})$ & No & No & $1-2$ & 1 & $0-1$ \\
\hline G2C (10 $\mu \mathrm{M})$ & No & No & $1-2$ & 1 & $0-1$ \\
\hline G3C $(5 \mu M)$ & No & No & 1 & 1 & $0-1$ \\
\hline Saline solution & No & No & $1-2$ & 1 & $0-1$ \\
\hline \multicolumn{6}{|c|}{ Just after instillation } \\
\hline & & & Limbal & Tarsal & \\
\hline Preparation & Tearing & Blepharospasm & Conjunctiva* & Conjunctiva* & Cornea* \\
\hline G1A $(10 \mu M)$ & No & No & $1-2$ & $0-1$ & 1 \\
\hline G2A (10 $\mu M)$ & $\mathrm{N}$ & No & $1-2$ & $0-1$ & 1 \\
\hline G3A (10 $\mu \mathrm{M})$ & No & No & $1-2$ & 1 & 1 \\
\hline G1C (10 $\mu \mathrm{M})$ & No & Slight & 2 & 1 & $0-1$ \\
\hline
\end{tabular}




$\begin{array}{cccccr}\text { G2C }(10 \mu \mathbf{M}) & \text { No } & \text { No } & 2 & 1 & 0-1 \\ \text { G3C }(5 \boldsymbol{\mu M}) & \text { No } & \text { No } & 1 & 1 & 0-1 \\ \text { Saline solution } & \text { No } & \text { No } & 1-2 & 1 & 0-1 \\ \text { (left eyes) } & & & & \end{array}$

$2 \mathrm{~h}$ post-instillation

\begin{tabular}{cccccc}
\hline Preparation & Tearing & Blepharospasm & $\begin{array}{c}\text { Limbal } \\
\text { Conjunctiva* }\end{array}$ & $\begin{array}{c}\text { Tarsal } \\
\text { Conjunctiva* }\end{array}$ & Cornea* \\
\hline G1A $(10 \mu M)$ & No & No & 1 & $0-1$ & 1 \\
G2A $(10 \mu M)$ & No & No & 1 & $0-1$ & 1 \\
G3A $(10 \mu M)$ & No & No & $1-2$ & 1 & 1 \\
G1C $(10 \mu M)$ & No & No & $0-1$ & 1 & $0-1$ \\
G2C $(10 \mu M)$ & No & No & $0-1$ & 1 & $0-1$ \\
G3C $(5 \mu M)$ & No & No & $1-2$ & 1 & $0-1$ \\
Saline solution & No & No & $1-2$ & & $0-1$ \\
(left eyes) & & & &
\end{tabular}

$6 \mathrm{~h}$ post-instillation

\begin{tabular}{cccccc}
\hline Preparation & Tearing & Blepharospasm & $\begin{array}{c}\text { Limbal } \\
\text { Conjunctiva* }\end{array}$ & $\begin{array}{c}\text { Tarsal } \\
\text { Conjunctiva* }\end{array}$ & Cornea* \\
\hline G1A (10 $\boldsymbol{\mu M})$ & No & No & 1 & $0-1$ & $0-1$ \\
G2A $(10 \mu M)$ & No & No & 1 & $0-1$ & $0-1$ \\
G3A (10 $\boldsymbol{\mu M})$ & No & No & $1-2$ & 1 & $0-1$ \\
G1C $(10 \mu M)$ & No & No & 1 & $0-1$ & $0-1$ \\
G2C $(10 \mu M)$ & No & No & 1 & 1 & $0-1$ \\
G3C (5 $\boldsymbol{\mu M})$ & No & No & $1-2$ & 1 & $0-1$ \\
Saline solution & No & No & $1-2$ & & $0-1$ \\
(left eyes) & & & & & \\
\hline
\end{tabular}

*, numeric scores based on the Efron scale: $0=$ normal; $1=$ trace; $2=$ mild; $3=$ moderate; $4=$ severe

Interaction of carbosilane dendrimers with transmembrane ocular mucins 
The carbosilane dendrimer concentrations used to assess the interaction between the dendrimers and transmembrane ocular mucins were the same as used in the in vivo tolerance studies. In these experiments, the behaviors of the anionic and cationic dendrimers in contact with ocular mucin were completely different from one another. The sensorgram values for the anionic dendrimers returned to almost zero after about $350 \mathrm{~s}$, indicating that the interaction between the dendrimers and mucin was nonpermanent (Figure 3a). In contrast, a significant portion of the cationic dendrimers in contact with the ocular mucin layer was retained in the glycoprotein layer, permanently modifying the RU signal (Figure 3b). The highest retention was observed for $5 \mu \mathrm{M}$ G3-C.
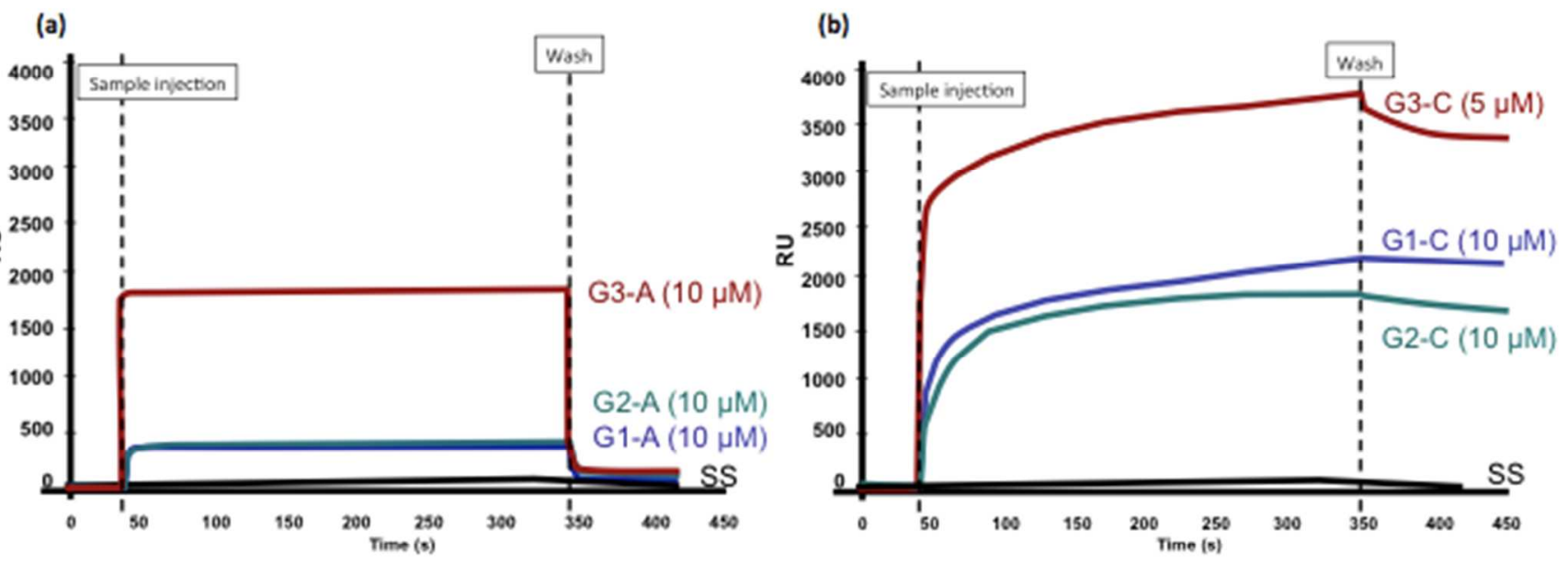

Figure 3

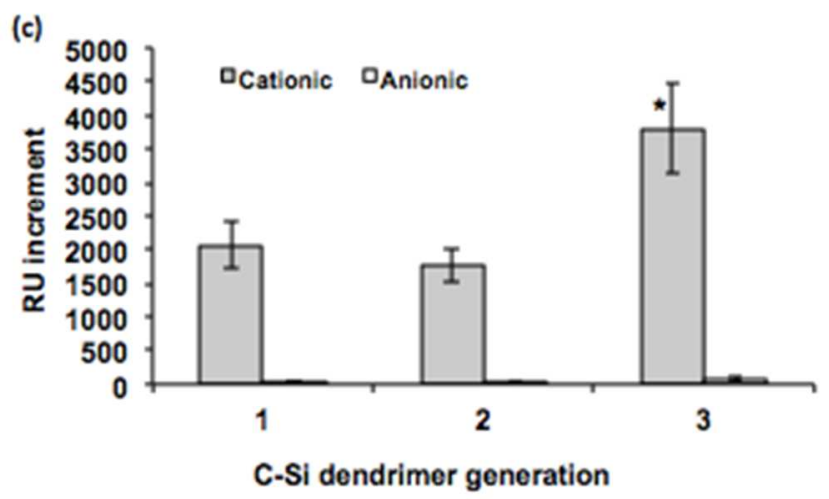


Figure 3: Dendrimer-transmembrane ocular mucin interaction measured by SPR spectroscopy. (a) Binding sensorgram of interaction between ocular transmembrane mucin and Generations $1-3$ of anionic carbosilane dendrimers. (b) Binding sensorgram of interaction between ocular transmembrane mucin and Generations $1-3$ of cationic carbosilane dendrimers. (c) Comparison of total cationic and anionic dendrimer binding, measured as RU increments, for each of the three generations of Gn-C and Gn-A dendrimers. RU, resonance units; SS, saline solution ${ }^{*}, \mathrm{p}<0.05$ for comparison of cationic dendrimer Generation 3 with cationic dendrimer Generations 1 and 2.

\section{Formulation characterization: $\mathrm{pH}$, surface tension, and osmolarity}

Based upon the mucoadhesion studies, the most promising candidate dendrimer was $5 \mu \mathrm{M}$ G3-C, which we then used to prepare the ACZ formulation (drug:polymer ratio 3149:1). The $\mathrm{pH}$, surface tension, and osmolarity of the ACZ solution in physiological saline media $(0.9 \%)$, with and without dendrimers (F2 and F1 respectively), were determined (Table 2).

Table 2: ACZ formulation pH, osmolarity and surface tension.

\begin{tabular}{cccc}
\hline ACZ formulation & $\mathbf{p H}$ & Osmolarity (mOsm) & Surface tension (mN/m) \\
\hline F1 & $5.6 \pm 0.1$ & $294.5 \pm 1.5$ & $54.7 \pm 0.7$ \\
F2 & $5.6 \pm 0.1$ & $289.4 \pm 2.1$ & $41.7 \pm 0.2$ \\
\hline
\end{tabular}

$\mathrm{F} 1,0.07 \% \mathrm{ACZ}$ in $0.9 \% \mathrm{NaCl} ; \mathrm{F} 2,0.07 \% \mathrm{ACZ}$ in a solution of $5 \mu \mathrm{M} \mathrm{G} 3-\mathrm{C}$ dendrimers and $0.9 \% \mathrm{NaCl}$. Data are expressed as means \pm SEMs $(n=3)$.

The pH of both F1 and F2 was 5.6 \pm 0.1 (Table 2). The osmolarity of the F1 formulation was 294.5 \pm 1.5 mOsm, which was not significantly different from the F2 osmolarity (Table 2). The surface tension of F2 was significantly lower than F1 $(\mathrm{p}<0.05)$, reflecting moderate tensioactive behavior for G3-C dendrimers. 


\section{Intraocular pressure}

Several activity parameters were selected to evaluate the effect of $5 \mu \mathrm{M}$ G3-C dendrimer on the ACZ-induced hypotension: onset time, peak effect time, maximal IOP reduction $\left(\Delta \mathrm{IOP}_{\max }\right)$, effective time period, and area under the IOP\% versus time curve $\left(\mathrm{AUC}_{0}{ }^{8 \mathrm{~h}}\right)$. Neither $0.9 \%$ saline (Figure $\left.4 \mathrm{a}\right)$ nor $0.9 \%$ saline with $5 \mu \mathrm{M}$ G3-C dendrimer (Figure 4b), both of which served as ACZ-free controls, had a hypotensive effect. For F1, composed of $0.07 \% \mathrm{ACZ}$ in $0.9 \%$ saline, the onset of hypotension was evident at $2 \mathrm{~h}$ post-instillation and lasted for four hours ( $\mathrm{p}<0.05$, Figure $4 \mathrm{a})$. For F2, composed of $0.07 \% \mathrm{ACZ}$ in $0.9 \%$ saline containing $5 \mu \mathrm{M}$ G3-C dendrimer, the hypotensive onset was evident at $1 \mathrm{~h}$ post-instillation and lasted for 7 hours $(\mathrm{p}<0.05$, Figure $4 \mathrm{~b})$. Furthermore, the presence of the dendrimer in the formulation slightly delayed the maximal $\Delta \mathrm{IOP}$ effect.

The maximum hypotensive effect, $22.6 \%$, was reached by F2, and it was significantly greater than the value achieved by $\mathrm{F} 1,17.2 \%(\mathrm{p}=0.0057$, Figure $4 \mathrm{c})$. The $\mathrm{AUC}_{0}{ }^{8 \mathrm{~h}}$ of $\mathrm{F} 1,72.8 \% \mathrm{~h}$, was lower than that for F2 ( $p=0.0137$, Figure $4 d)$. The efficacy of the formulations, as measured by the confidence intervals of the $\mathrm{AUC}_{0}{ }^{8 \mathrm{~h}}$ and the $\Delta \mathrm{IOP}_{\text {max }}$, was significantly higher for $\mathrm{F} 2$ than $\mathrm{F} 1$ (Figure 5). 

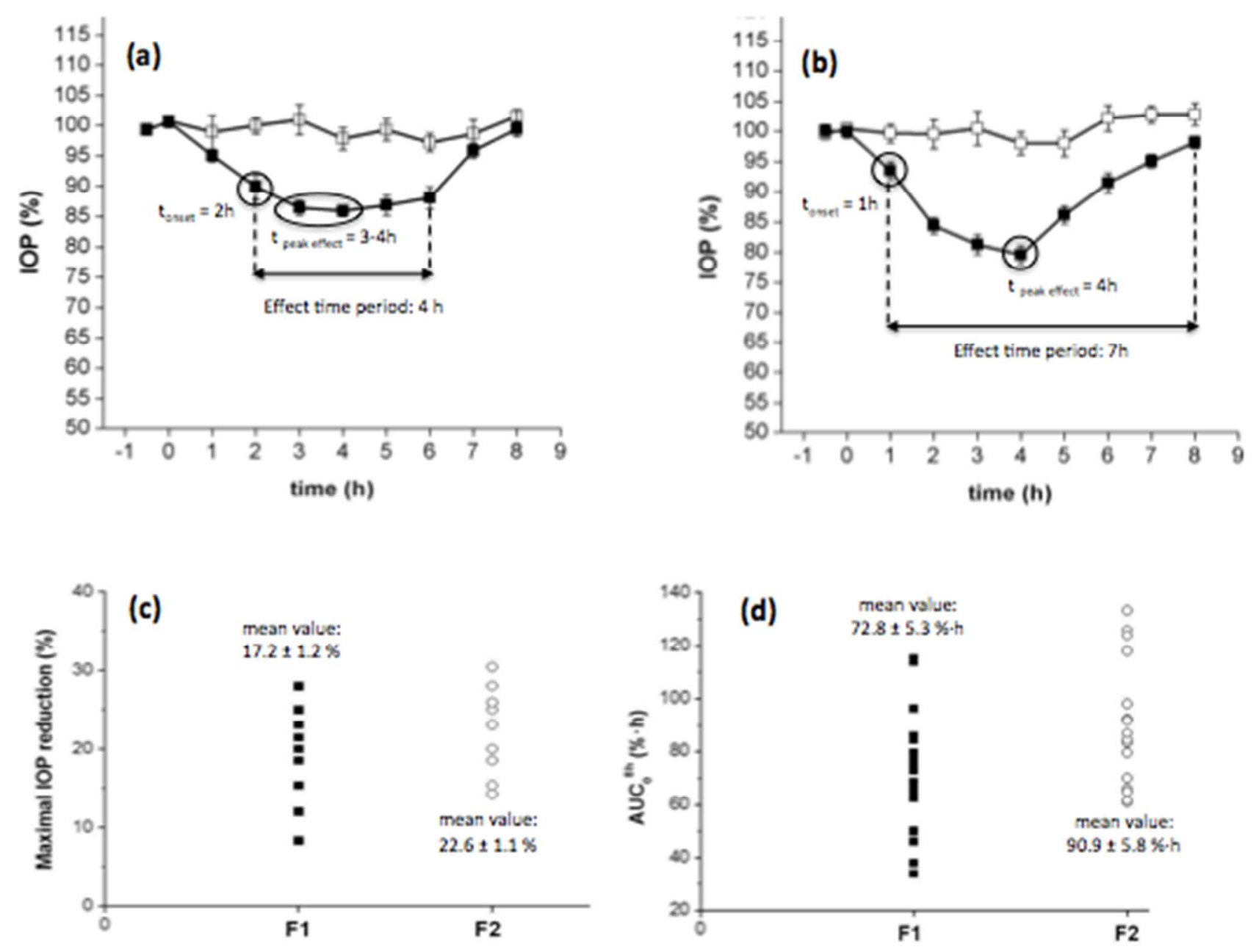

Figure 4

Figure 4: (a) IOP after instillation of $25 \mu \mathrm{L}$ of $\mathrm{F} 1$ composed of $0.07 \% \mathrm{ACZ}$ in $0.9 \%$ saline (black squares) or the vehicle composed of $0.9 \%$ saline (white squares). (b) IOP after instillation of $25 \mu \mathrm{L}$ of F2 composed of $0.07 \% \mathrm{ACZ}$ in $0.9 \%$ saline containing $5 \mu \mathrm{M}$ G3-C dendrimer (black squares), and the vehicle composed of $0.9 \%$ saline containing $5 \mu \mathrm{M}$ 3G-C dendrimer (white squares). (c) Maximal IOP reduction $\left(\Delta \mathrm{IOP}_{\text {máx }}, \%\right)$ induced by $\mathrm{F} 1$ and $\mathrm{F} 2$. (d) Area under the curve of the $\Delta \mathrm{IOP}(\%)$ versus time (h) from 0 to 8 hours $\left(\mathrm{AUC}_{0}{ }^{8 \mathrm{~h}}\right)$ induced by $\mathrm{F} 1$ and $\mathrm{F} 2$. 


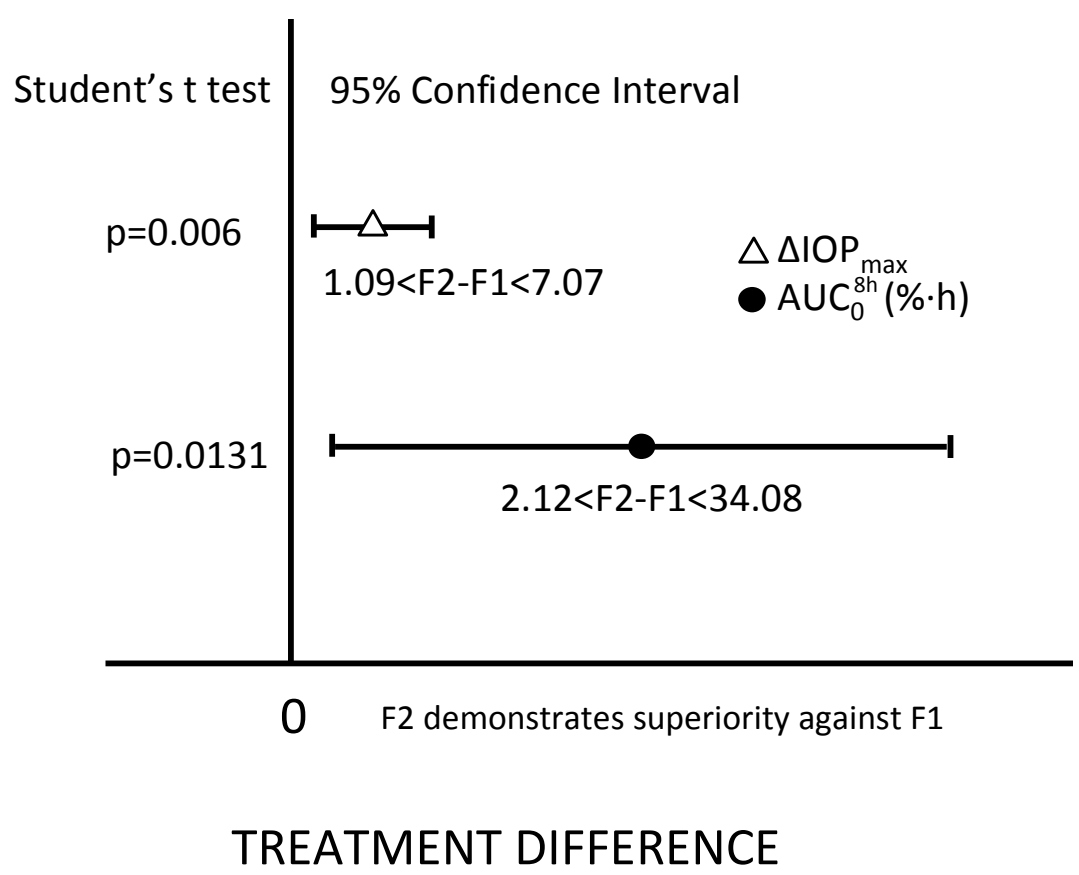

Figure 5: Relationship between the two mean difference test (Student's t-test) and confidence intervals for the difference of the means. Values to the right of zero correspond to a better response to F2 than to $\mathrm{F} 1$ for both $\mathrm{AUC}_{0}{ }^{8 \mathrm{~h}}$ and $\Delta \mathrm{IOP}_{\max }$ F1, $0.07 \% \mathrm{ACZ}$ in $0.9 \%$ saline; $\mathrm{F} 2,0.07 \% \mathrm{ACZ}$ in $0.9 \%$ saline containing $5 \mu \mathrm{M}$ G3-C dendrimer.

\section{Discussion}

Dendrimers offer very attractive features as novel drug nanocarrier systems. These features include a controlled and totally known chemical structure and charge as well as the possibility of interaction with biological tissues and drugs. ${ }^{16-19}$ However, their use in ophthalmology remains almost unexplored in contrast to other administration routes (oral, intravenous, or transdermal) where extensive progress has been achieved. ${ }^{20,21}$ Only a few authors have explored the potential of dendrimers as drug carriers in 
ophthalmology. Vandamme and Brobeck demonstrated that the co-administration of PAMAM dendrimers with pilocarpine or tropicamide prolonged and sustained the pharmacological effect of the drugs in comparison to classical drug solutions. ${ }^{4}$ More recently, using surface biosensors we demonstrated a strong interaction between PAMAM dendrimers and ocular transmembrane mucins. ${ }^{6}$ According to these initial works, it is worth considering dendrimers as useful tools to increase drug retention time on the ocular surface, which in turn could reduce the administration frequency and thus increase patient compliance. With this idea, we generated new dendrimers based on a carbosilane structure, and evaluated the suitability as eyedrop excipients. The carbosilane skeleton provides these dendrimers with unique advantages. Among them, a simple method for synthesis, chemical inertia of the carbon-carbon and carbon-silicon bonds that prevent secondary reactions, and importantly, a highly hydrophobic character that allows better interaction of the dendrimer with biological membranes and/or hydrophobic drugs.

Because this was the first time that these structures have been evaluated for ocular administration, we performed tolerance studies to determine the suitable concentration for ocular tissues. The initial in vitro tolerance assay with human ocular cell lines showed higher toxicity for the cationic dendrimers than for the anionic ones. These results are in concordance with other cytotoxicity studies performed in different cell lines. ${ }^{22,23}$ Some authors have attributed the cytotoxicity of cationic dendrimers to the high density of positive charges that increases with each generation of dendrimer and that could disrupt the cell membranes. ${ }^{24-26}$ Nevertheless, several studies have demonstrated that cationic dendrimers have the same or lower toxicity than polycationic linear polymers. ${ }^{26-28}$ Indeed, Vandamme and Brobeck, for example, observed better tolerance results for PAMAM dendrimers than for linear polymers (hydroxypropylmethyl cellulose and $\mathrm{Carbopol}^{\circledR}$ ) on the ocular surface. ${ }^{4}$ Furthermore, Bermejo and co-workers evaluated the biocompatibility of carbosilane dendrimers in primary cell cultures of peripheral blood mononuclear cells and erythrocytes and found they had good toxicity profiles over extended periods of time. ${ }^{7}$ Based upon our in vitro tolerance studies, we administered anionic and cationic carbosilane dendrimer solutions to the 
ocular surface of rabbit eyes and found no alterations or discomfort. This further confirmed that the polymer concentrations selected in the in vitro study were suitable for ocular administration in animals.

We next determined the possible interaction of carbosilane dendrimers with elements of the ocular surface, specifically with corneal transmembrane mucins. These high molecular weight glycoproteins cover the corneal and conjunctival epithelia, anchor the precorneal tear film, and play an essential role in mucoadhesion. ${ }^{29}$ We used surface biosensors with high sensitivity, so only small amounts of ligand and analyte were needed. ${ }^{30-32}$ Because this is the first in vitro method specifically designed to evaluate interfacial mucin-polymer interactions, we recently proposed it as a very valuable tool in understanding the interactions of ocular transmembrane mucins with polymers or other macromolecules, especially when low amounts of mucins are available. ${ }^{6}$

The cationic dendrimer G3-C exhibited a significant permanent chemical adherence to the ocular transmembrane mucins. This interaction might be governed by electrostatic interactions between primary amino groups of the dendrimers and the sialic acid and sulphated groups present in the glycosylated chains of the mucins. In a previous work, this technique showed that the anionic dendrimer PAMAM$\mathrm{COOH}$ permanently interacted with the ocular mucin layer, probably due to the formation of hydrogen bonds between charged carboxylic groups of the dendrimer and the sugar residue on the mucins side chains. ${ }^{6}$ However, the anionic carbosilane dendrimers used in the current work had a more hydrophobic backbone and non-protonated terminal carboxylate groups compared to PAMAM. Thus the formation of such interactions between the anionic carbosilane dendrimers and the mucins was not favored, probably because the electrostatic repulsion with the negatively charged mucin surface was strong enough to prevent permanent chemical interaction. Due to the lack of mucin interaction, we chose not to pursue the anionic dendrimers in further studies.

ACZ was chosen as the model drug to evaluate the potential of enhancing ocular surface bioavailability. This carbonic anhydrase inhibitor has a potent specific effect in reducing aqueous humor 
1

production, and therefore, intraocular pressure. It has high potential in the treatment of glaucoma, in which high and persistent IOP promotes damage of the optic disk at the juncture of the optic nerve and retina, provoking irreversible retinal degeneration and blindness. However, the use of ACZ is limited because it has low bioavailability after ocular instillation due to low aqueous solubility and limited ocular penetration. For those same reasons, ACZ has gained attention as a model drug to test different strategies to increase bioavailability after ophthalmic application. Some efforts have been explored with this model drug, from the classical approach of using drug suspensions in polymeric solutions ${ }^{33}$ to the use of more structured and sophisticated systems such as liposomes, ${ }^{34}$ cyclodextrin complexes, ${ }^{35,36}$ niosomes, ${ }^{37}$ nanoparticles, ${ }^{38}$ and commercial poly(propyleneimine) dendrimers. ${ }^{39}$ In those studies, ACZ efficacy was improved; however in some cases, tolerance studies were either not performed or they were unsuitable. Consequently, the potential cytotoxicity of the formulations is unknown.

In this work, we performed the essential in vitro and in vivo tolerance studies that allowed us to select an innocuous final prototype for in vivo efficacy studies. $\mathrm{pH}$ and osmolarity studies confirmed that the behavior of the selected formulation is totally compatible with the ocular surface. ${ }^{40}$ The very simplistic approach explored takes advantage of the high interaction of cationic carbosilane dendrimers with ocular transmembrane mucins as well as the tensioactive behavior observed for these polymers. The inclusion of a very low amount of cationic carbosilane dendrimer, $5 \mu \mathrm{M}$ G3-C, in the ACZ solution in saline media resulted in a more rapid and extended hypotensive effect, leading to a significant increment in the efficacy. The low drug:polymer ratio used in this formulation indicates that most of the drug must not be directly attached to the dendrimer structure. Under these conditions, the inclusion of the cationic carbosilane dendrimers might promote the formation of a well-spread aqueous eyedrop layer, favored by the tensioactive nature of the formulation, that is strongly attached to the ocular surface and that enhances the retention of the drug. In contrast to formulations containing linear polymers, this increment in the 
retention time would be achieved without modifying the viscosity of the tear film, preventing the discomfort typically associated to these viscous media. ${ }^{29}$

\section{Conclusions}

The high chemical versatility and the small and controlled size of dendrimers allow the design of preparations able to interact with biological molecules, representing a simplified alternative to more complex systems for drug administration. In this work, we evaluated the potential use of ionic C-Si dendrimers for ocular administration. In vitro and in vivo tolerance studies were performed to select an innocuous prototype.

In this proof of concept, the inclusion of only a very low amount of cationic carbosilane dendrimer was well tolerated and improved the hypotensive effect of an ACZ solution by decreasing the onset time and increasing the duration after a single instillation. This is the first work demonstrating that carbosilane dendrimers can enhance the bioavailability of drugs administered topically in the eye.

\section{Acknowledgements}

The authors are grateful to Prof. I. Gipson (Schepens Eye Research Institute, Boston, MA, USA) for supplying the human corneal-limbal epithelial cell line and to IOBA (Instituto de Oftalmología y Biología Aplicada, Vallodolid, Spain) for providing the human conjunctiva epithelial cell line. The authors also thank Ms. Woodward and Ms. Noiray for their help in the mucoadhesion studies.

Dr. Bravo-Osuna thanks the "Institute de Chimie du Centre National de Recherche Scientifique du France (CNRS)" for financial support. The authors thank the Research Group UCM 920415, RETICS OFTARED (RD 12/0034) and MAT2013-43127-R (MINECO) for financial support. This work has been also supported by grants from CTQ-2014-54004-P (MINECO), and Consortium NANODENDMED ref S2011/BMD-2351 (CAM) to University of Alcalá. CIBER-BBN is an initiative funded by the VI National R\&D\&i Plan 2008-2011, Iniciativa Ingenio 2010, Consolider Program, CIBER Actions and financed by the Instituto de Salud Carlos III with assistance from the European Regional Development 


\author{
Fund. Dr. Argüeso thanks the US National Institutes of Health for financial support through the National \\ Eye Institute Grant No. R01EY014847 (PA).
}

\title{
Notes and references
}

Electronic Supplementary Information (ESI) available: Drawing and NMR spectra of compounds described in the paper. 


\section{REFERENCES}

(1) Abdelkader H.; Alany R.G.; Controlled and continuous release ocular drug delivery systems: pros and cons. Curr.Drug Del. 2012;9,421-430.

(2) Urtti A.. Challenges and obstacles of ocular pharmacokinetics and drug delivery. Adv. Drug Del. Rev.. 2006;58,1131-1135.

(3) Andres-Guerrero V.; Molina-Martinez I.T.; Peral A.; de las Heras B.; Pintor J.; Herrero-Vanrell R.. The use of mucoadhesive polymers to enhance the hypotensive effect of a melatonin analogue, 5-MCANAT, in rabbit eyes. Invest. Ophthalmol. Vis. Sci.. 2011;52, 1507-1515.

(4) Vandamme T.F.; Brobeck L.. Poly(amidoamine) dendrimers as ophthalmic vehicles for ocular delivery of pilocarpine nitrate and tropicamide. J. Control. Release.2005;102, 23-38.

(5) Yang H.; Tyagi P.; Kadam R.S.; Holden C.A.; Kompella U.B.. Hybrid dendrimer hydrogel/PLGA nanoparticle platform sustains drug delivery for one week and antiglaucoma effects for four days following one-time topical administration. ACS nano. 2012;6,7595-7606.

(6) Bravo-Osuna I., Noiray M.; Briand E.; Woodward A.M.; Argueso P.; Molina Martinez; I.T. HerreroVanrell R.; Ponchel G.. Interfacial interaction between transmembrane ocular mucins and adhesive polymers and dendrimers analyzed by surface plasmon resonance. Pharm. Res. 2012;29, 2329-2340.

(7) Bermejo J.F.; Ortega P.; Chonco L.; Eritja R.; Samaniego R.; Mullner M.; de Jesús E.; de la Mata F. J.; Flores J.C.; Gómez R.; Muñoz-Fernández A. . Water-soluble carbosilane dendrimers: synthesis biocompatibility and complexation with oligonucleotides; evaluation for medical applications. Chem.. $2007 ; 13,483-495$.

(8) Ortega P.; Chonco L.; de Jesús E.; de la Mata F. J.; Fernández G.; Flores J. C.; Gómez R.; Serramía M. J.; Muñoz-Fernández M. A.. Novel water-soluble carbosilane dendrimers: Synthesis and biocompatibility. Eur J Inorg Chem. 2006,1388-1396. 
(9) Rasines B.; Sanchez-Nieves J.; Maiolo M.; Maly M., Chonco L.; Jimenez J.L.; Muñoz-Fernández M. A.; de la Mata F. J.; Gómez R.. Synthesis, structure and molecular modelling of anionic carbosilane dendrimers. Dalton Trans. 2012;41, 12733-12748.

(10) Sánchez-Nieves J.; Muñoz-Fernández M. Á.; Gómez R.; de la Mata F. J.. Synthesis of carbosilane dendrons and dendrimers derived from 1,3,5-trihydroxybenzene. Tetra. 2010;66: 9203-9213.

(11) Andres-Guerrero V.; Alarma-Estrany P.; Molina-Martinez I.T.; Peral A.; Herrero-Vanrell R.; Pintor J.. Ophthalmic formulations of the intraocular hypotensive melatonin agent 5-MCA-NAT. Exp. Eye Res. 2009;88, 504-511.

(12) Efron N.. Grading scales for contact lens complications. Ophthalmic. Physiol. Opt. 1998;18, 182186.

(13) Fan X.; White I.M.; Shopova S.I.; Zhu H.; Suter J.D.; Sun Y.. Sensitive optical biosensors for unlabeled targets: a review. Anal. Chim. Acta. 2008;620: 8-26.

(14) Purslow C.; Wolffsohn J.S.. Ocular surface temperature: a review. Eye \& contact lens. 2005;31, 117123.

(15) Sánchez-Nieves J.; Pulido D.; Lorente R.; Muñoz-Fernández M.A; Albericio F.; Royo M.; Gómez R.; de la Mata F. J.. Amphiphilic Cationic Carbosilane PEG Dendrimers: Synthesis and Applications in Gene Therapy. Eur J Med Chem. 2014;76, 43-52.

(16) Kitchens K.M.; Kolhatkar R.B.; Swaan P.W.; Eddington N.D.; Ghandehari H.. Transport of poly(amidoamine) dendrimers across Caco-2 cell monolayers: Influence of size, charge and fluorescent labeling. Pharm. Res. 2006;23, 2818-2826.

(17) Hong S.; Leroueil P.R.; Janus E.K.; Peters J.L.; Kober M.M.; Islam M.T.; Orr B. G.; Baker J. R.; Bariszak Holl M. M... Interaction of polycationic polymers with supported lipid bilayers and cells: nanoscale hole formation and enhanced membrane permeability. Bioconj. Chem.. 2006;17, 728-734. 
(18) Gupta U.; Agashe H.B.; Asthana A.; Jain N.K.. A review of in vitro-in vivo investigations on dendrimers: the novel nanoscopic drug carriers. Nanomed.Nanotechn. Biol. Med.. 2006;2, 66-73.

(19) Pietersz G.A.; Tang C.K.; Apostolopoulos V.. Structure and design of polycationic carriers for gene delivery. Mini reviews in medicinal chemistry. 2006;6, 1285-1298.

(20) Cheng Y.; Xu Z.; Ma M.; Xu T. . Dendrimers as drug carriers: applications in different routes of drug administration. J. Pharm. Sci. 2008;97, 123-143.

(21) Kukowska-Latallo J.F., Candido K.A., Cao Z.; Nigavekar S.S.; Majoros I.J.; Thomas T.P.; Balogh L.P.; Khan M.K.; Baker J.R.. Nanoparticle targeting of anticancer drug improves therapeutic response in animal model of human epithelial cancer. Cancer Res. 2005;65, 5317-5324.

(22) Jevprasesphant R.; Penny J.; Attwood D., McKeown N.B.; D'Emanuele A.. Engineering of dendrimer surfaces to enhance transepithelial transport and reduce cytotoxicity. Pharm. Res. 2003;20, $1543-1550$.

(23) Aillon K.L.; Xie Y., El-Gendy N.; Berkland C.J.; Forrest M.L.. Effects of nanomaterial physicochemical properties on in vivo toxicity. Adv. Drug Der. Rev. 2009;61, 457-466.

(24) Dufes C.; Uchegbu I.F.; Schatzlein A.G.. Dendrimers in gene delivery. Adv. Drug Del. Rev. 2005;57, 2177-2202.

(25) Duncan R.;. Izzo L. Dendrimer biocompatibility and toxicity. Adv. Drug Del. Rev.. 2005;57, 22152237.

(26) Boas U.; Heegaard P.M.. Dendrimers in drug research. Chem. Soc. Rev. 2004;33, 43-63.

(27) Fischer D.; Li Y.; Ahlemeyer B.; Krieglstein J.; Kissel T.. In vitro cytotoxicity testing of polycations: influence of polymer structure on cell viability and hemolysis. Biomat.. 2003;24, 1121-1131.

(28) Reddy J. A.; Dean D.; Kennedy M.D.; Low P.S.. Optimization of folate-conjugated liposomal vectors for folate receptor-mediated gene therapy. J. Pharm. Sci.. 1999;88, 1112-1118. 
(29) Ludwig A.. The use of mucoadhesive polymers in ocular drug delivery. Adv. Drug Del. Rev. $2005 ; 57,1595-1639$.

(30) Besenicar M.; Macek P.; Lakey J.H.; Anderluh G.. Surface plasmon resonance in protein-membrane interactions. Chem. Phys Lip.. 2006;141, 169-178.

(31) Oli M.W.; McArthur W.P.; Brady L.J.; A whole cell BIAcore assay to evaluate P1-mediated adherence of Streptococcus mutans to human salivary agglutinin and inhibition by specific antibodies. $J$. Microbiol. Met.. 2006;65, 503-511.

(32) Hoa X.D.; Kirk A.G.; Tabrizian M.. Towards integrated and sensitive surface plasmon resonance biosensors: a review of recent progress. Biosens.Bioelectr.. 2007;23, 151-160.

(33) Kaur I.P.; Singh M.; Kanwar M.. Formulation and evaluation of ophthalmic preparations of acetazolamide. Int. J. Pharm. 2000;199, 119-127.

(34) Omaima N.;. El-Gazayerly A.H.H. Preparation and evaluation of acetazolamide liposomes as an ocular delivery system. Int. J. Pharm. 1997;158, 121-127.

(35) Ammar H.O.; El-Nahhas S.A.; Khalil R.M.. Cyclodextrins in acetazolamide eye drop formulations. Die Pharmazie. 1998;53, 559-562.

(36) Palma S.D.; Tartara L.I.; Quinteros D.; Allemandi D.A.; Longhi M.R.; Granero G.E.. An efficient ternary complex of acetazolamide with HP-ss-CD and TEA for topical ocular administration. J. Control. Release 2009;138, 24-31.

(37) Aggarwal D.; Garg A.; Kaur I.P.. Development of a topical niosomal preparation of acetazolamide: preparation and evaluation. J Pharm. Pharmacol.. 2004;56, 1509-1517.

(38) Tartara L.I.; Quinteros D.A.; Saino V.; Allemandi D.A.; Palma S.D.. Improvement of acetazolamide ocular permeation using ascorbyl laurate nanostructures as drug delivery system. J. Ocular Pharmacol. Ther. 2012;28, 102-109. 
(39) Mishra V.; Jain N.K. Acetazolamide encapsulated dendritic nano-architectures for effective glaucoma management in rabbits. Int. J. Pharm.. 2014;461, 380-390.

(40) Garcia-Valldecabres M.; Lopez-Alemany A.; Refojo M.F.. pH stability of ophthalmic solutions. Optometry. 2004;75, 161-8. 


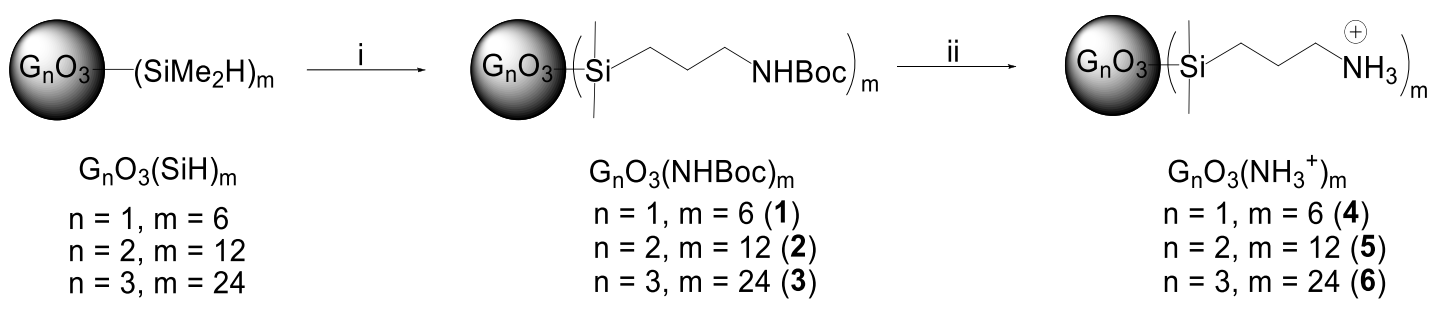




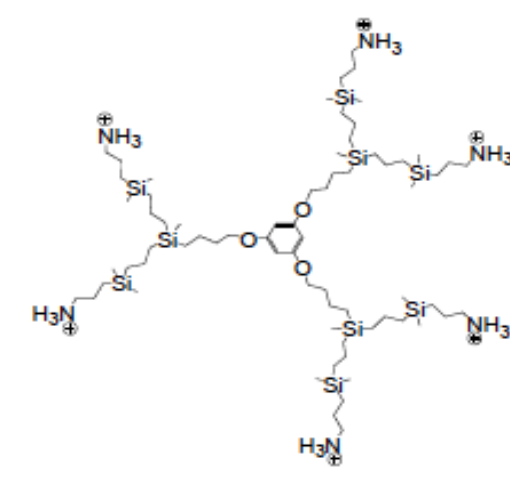

4 (G1-C)

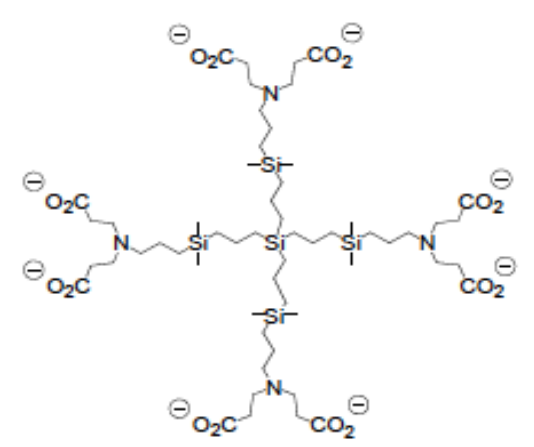

(G1-A)
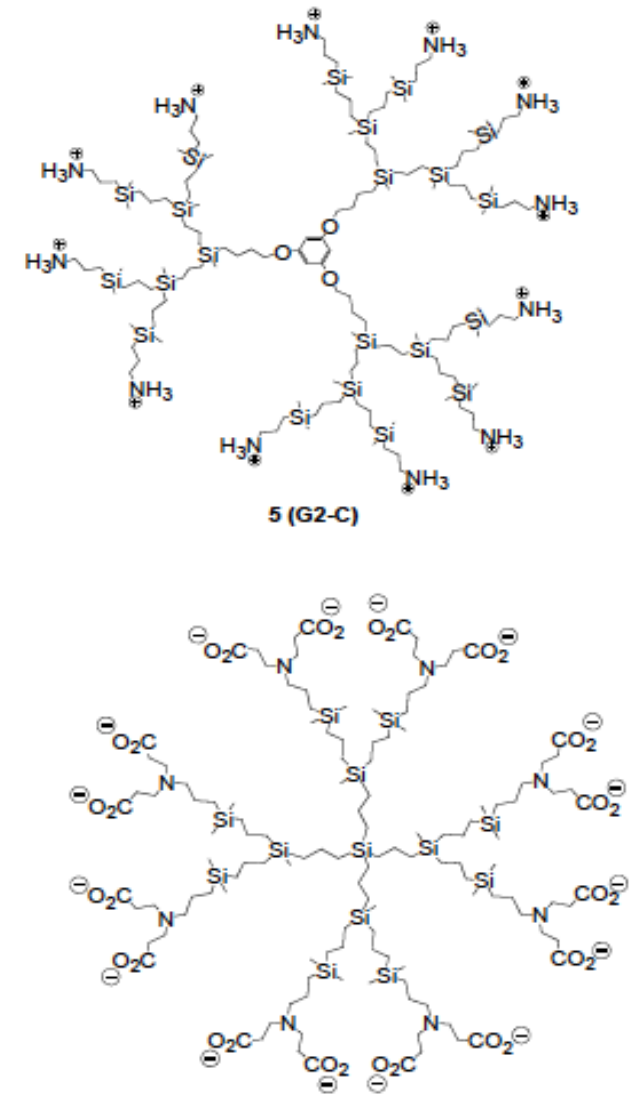

(G2-A)
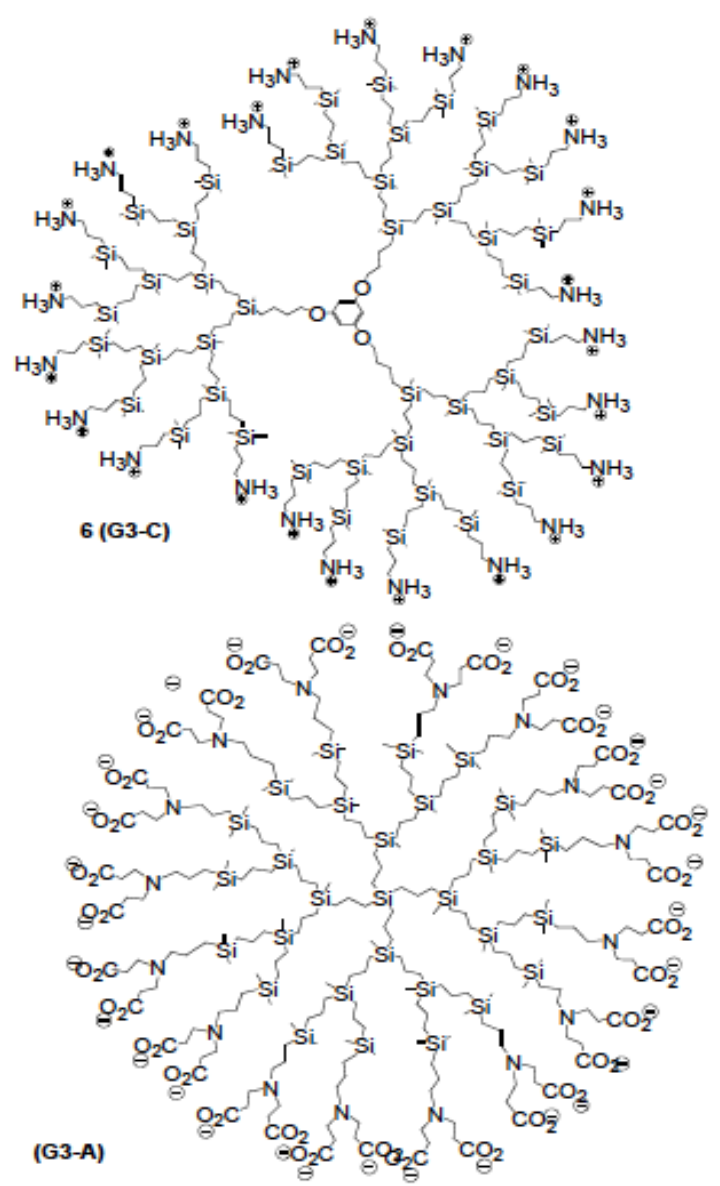


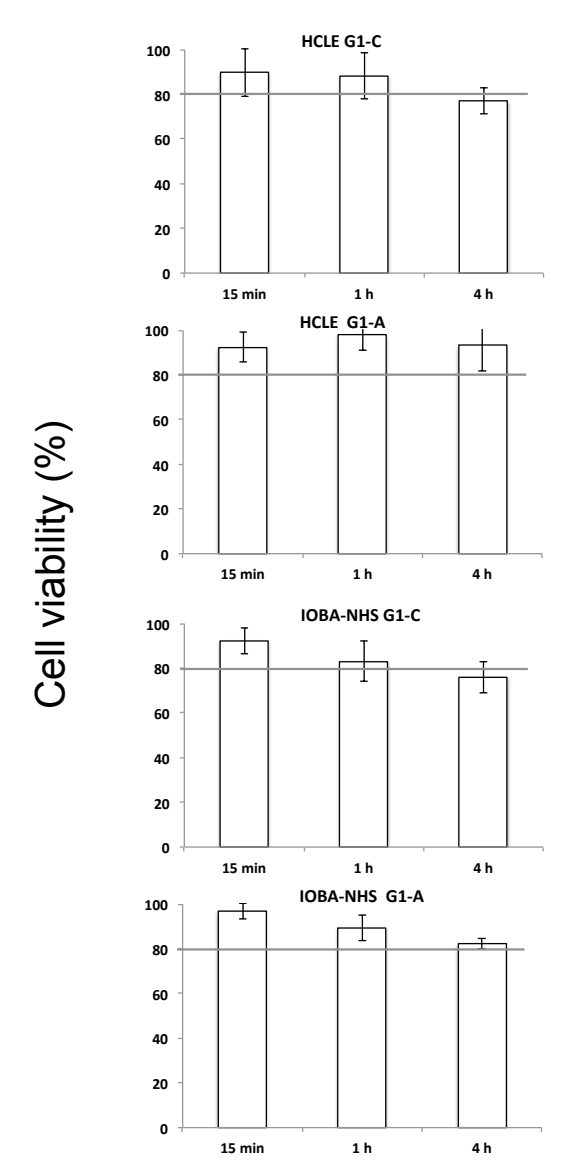

Figure 2
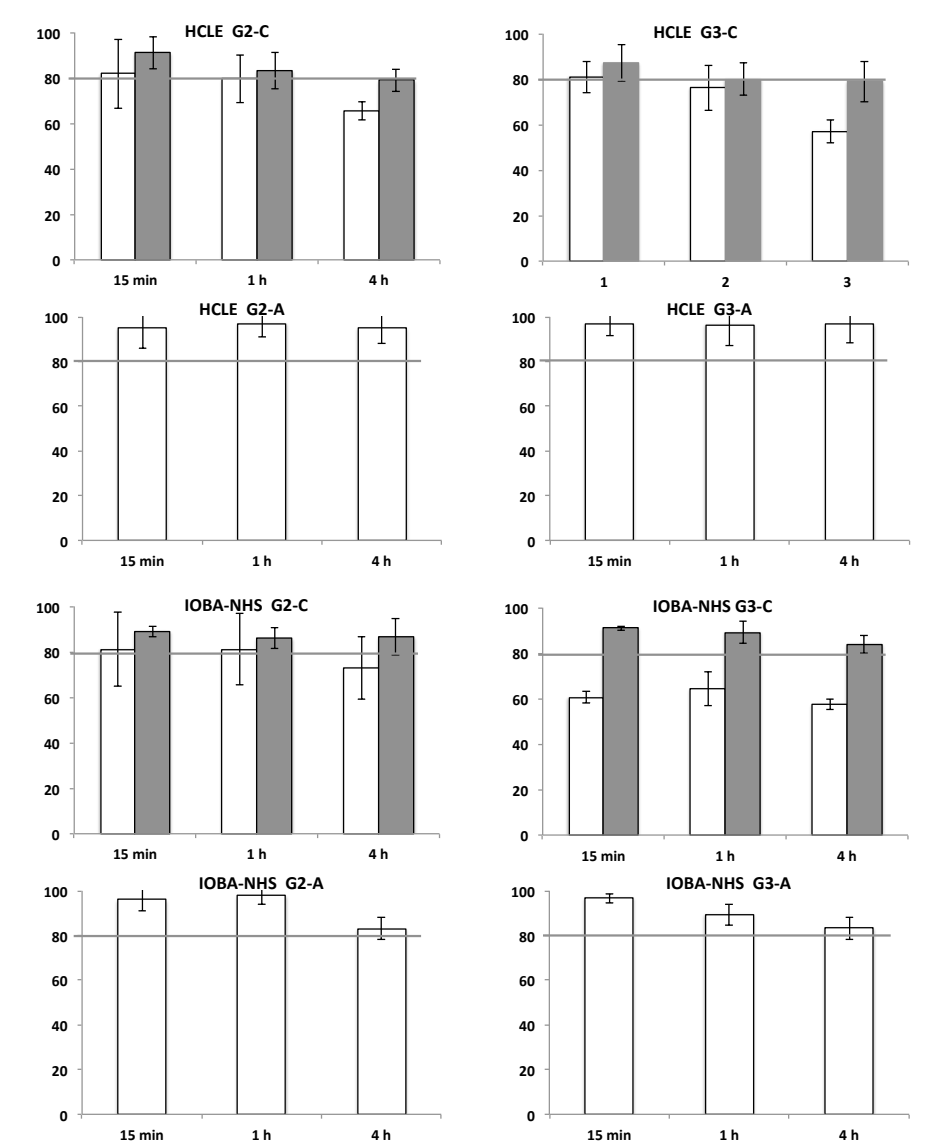

Contact time 

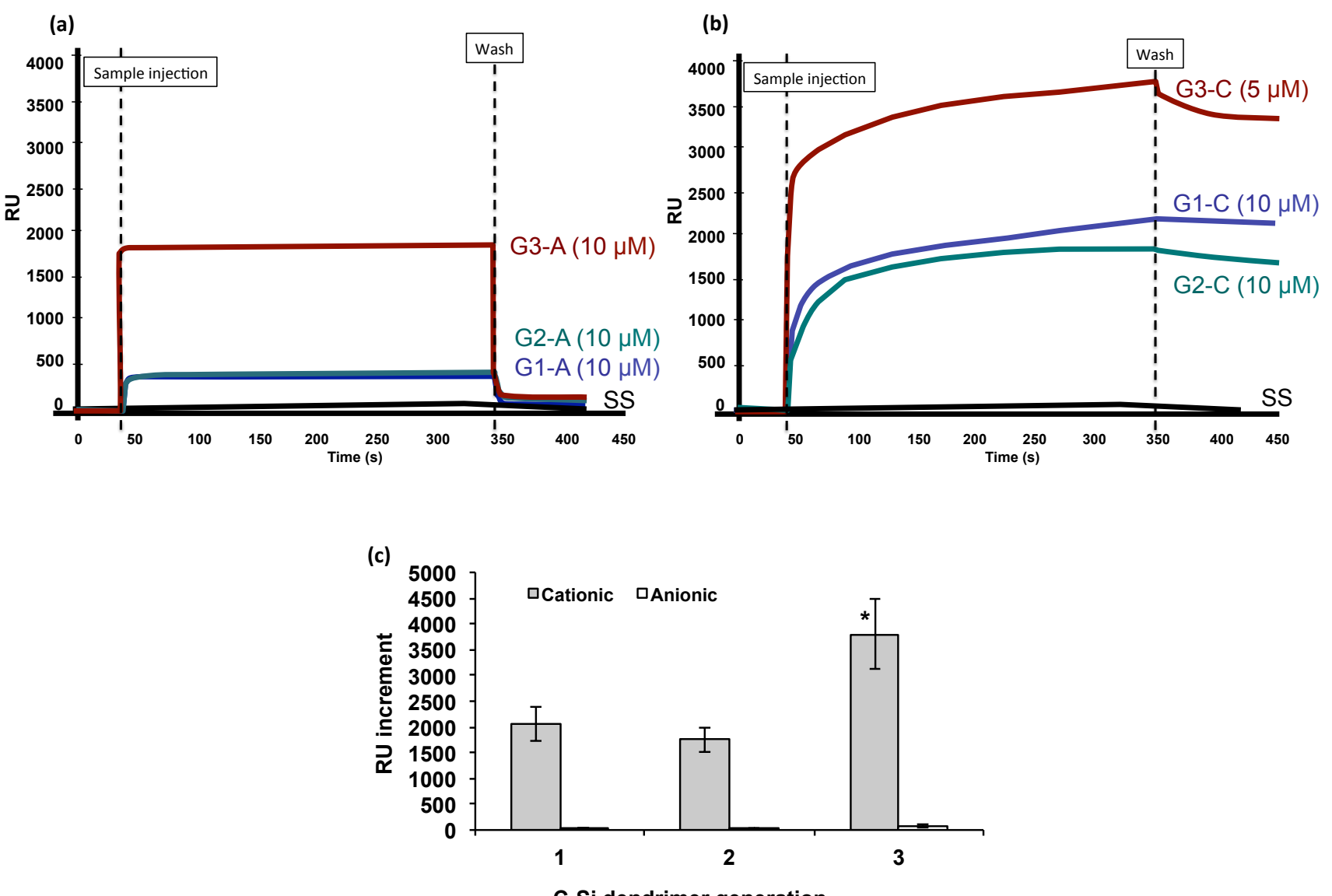

Figure 3 

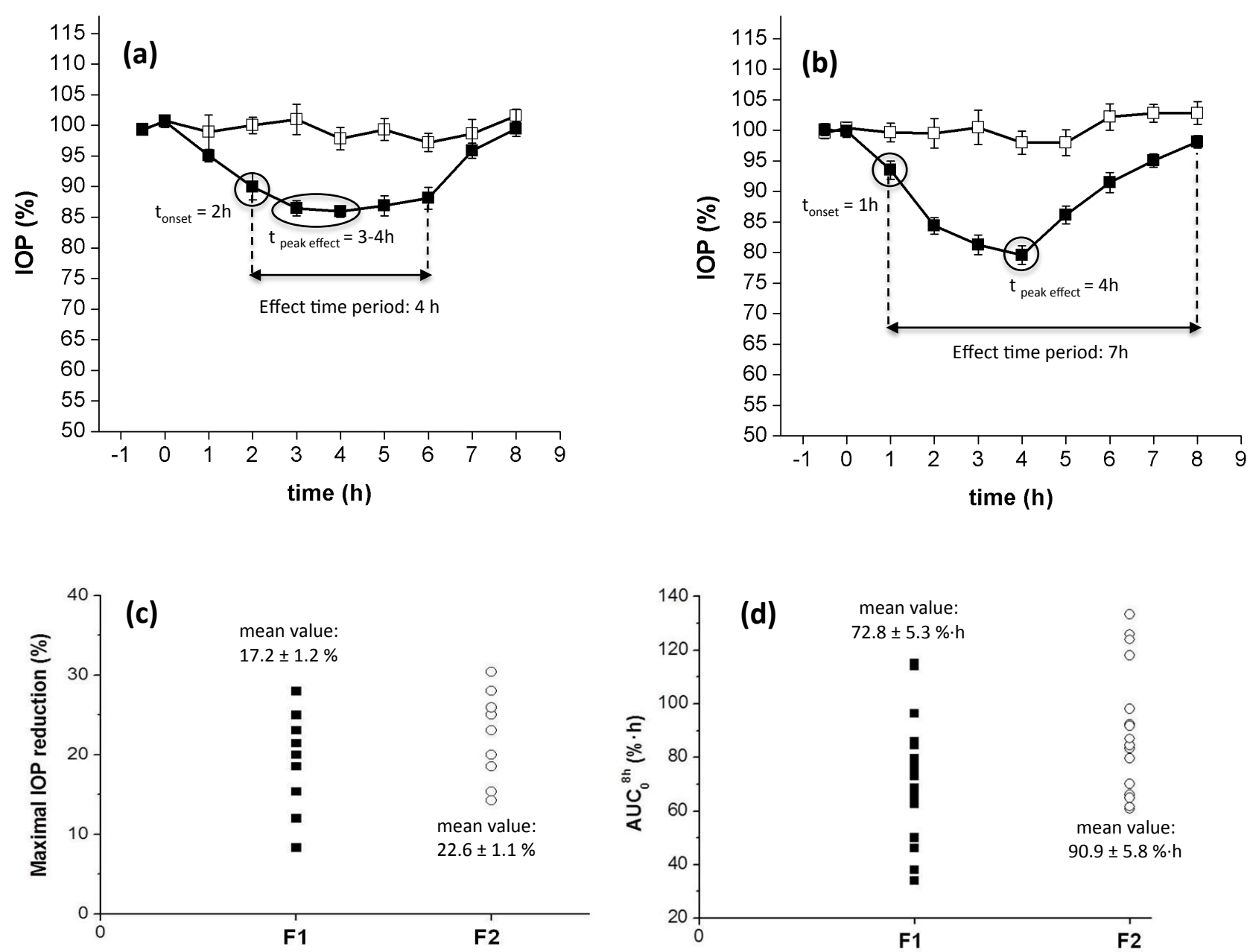

\section{Figure 4}




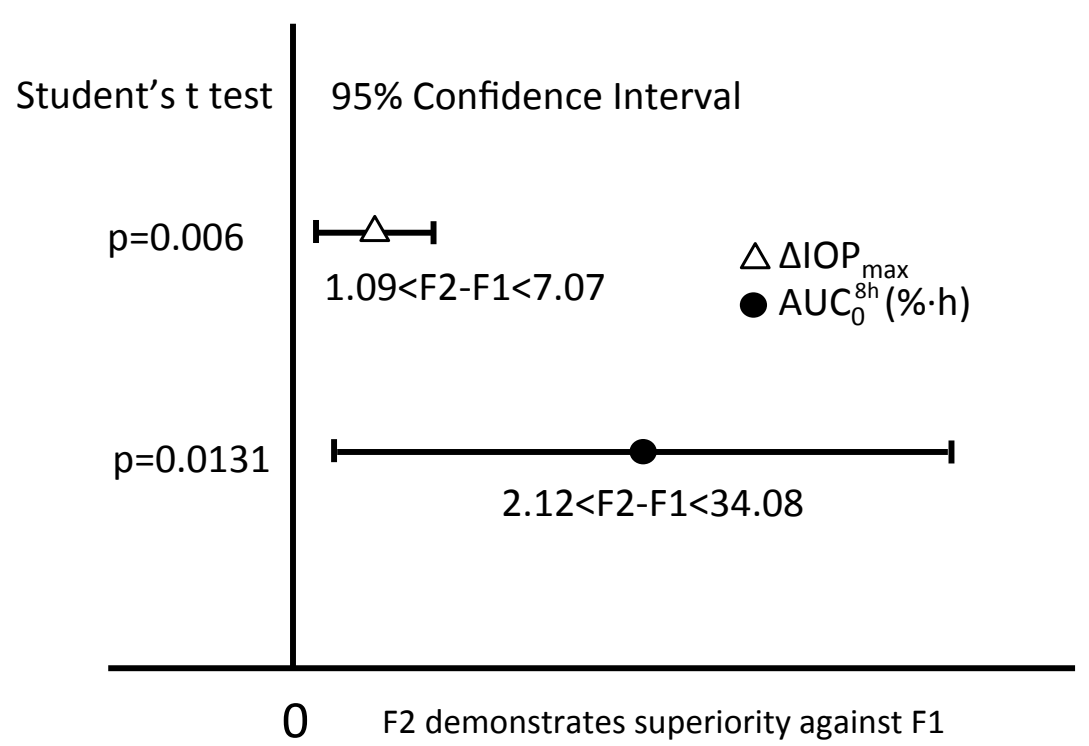

\section{TREATMENT DIFFERENCE}

